\title{
1 Atmospheric nitrate export in streams along a montane to
}

\section{urban gradient}

3

4 Ilann Bourgeois ${ }^{a, b, \S}$, Joel Savarino ${ }^{a}$, Julien Némery ${ }^{a}$, Nicolas Caillon ${ }^{a}$, Sarah

5 Albertin $^{a}$, Franck Delbart ${ }^{c}$, Didier Voisin ${ }^{a}$, and Jean-Christophe Clément ${ }^{b, d}$

6

7 aUniversité Grenoble Alpes, CNRS, IRD, Grenoble INP*, IGE, F-38000, Grenoble,

8 France

9 bUniversité Grenoble Alpes, CNRS, LECA, F-38000, Grenoble, France

10 'Université Grenoble Alpes, CNRS, SAJF, F-38000, Grenoble, France

11 Université Savoie Mont Blanc, INRA, CARRTEL, F-74200, Thonon-Les Bains,

12 France

13

14 * Institute of Engineering Univ. Grenoble Alpes

15 §ilann.bourgeois@noaa.gov 


\section{Abstract}

17 Nitrogen $(\mathrm{N})$ emissions associated with urbanization exacerbate the atmospheric nitrogen influx to remote ecosystems - like mountains -, leading to well-documented detrimental effects on ecosystems (e.g., soil acidification, pollution of freshwaters). Here, the aim was to evaluate the importance and fate of $\mathrm{N}$ deposition in a watershed

21

22

Keywords: Nitrogen, deposition, $\Delta^{17} \mathrm{O}$, subalpine, isotope, Lautaret $\delta^{15} \mathrm{~N}, \delta^{18} \mathrm{O}$ of nitrate, $\delta^{2} \mathrm{H}$ and $\delta^{18} \mathrm{O}$ of water). In this setting, the montane streams had higher proportions of atmospheric nitrate compared to urban streams, and exported more atmospheric nitrate on a yearly basis ( 0.35 vs $\left.0.10 \mathrm{~kg}^{-\mathrm{N} \mathrm{ha}} \mathrm{hr}^{-1} \mathrm{yr}^{-1}\right) . \mathrm{In}$ urban areas, nitrate exports were driven by groundwater, whereas in the catchment head nitrate exports were dominated by surface runoffs. The main sources of nitrate to the montane streams were microbial nitrification and atmospheric deposition whereas microbial nitrification and sewage leakages contributed most to urban streams. Based on the measurement of $\delta^{15} \mathrm{~N}$ and $\delta^{18} \mathrm{O}-\mathrm{NO}_{3}{ }^{-}$, biological processes such as denitrification or $\mathrm{N}$ assimilation were not predominant in any streams in this study. The observed low $\delta^{15} \mathrm{~N}$ and $\delta^{18} \mathrm{O}$ range of terrestrial nitrate (i.e., nitrate not coming from atmospheric deposition) in surface water compared to literature suggests that atmospheric deposition may be underestimated as a direct source of N. 


\section{Highlights}

40

41 How is nitrogen deposition reflected in streams $\mathrm{NO}_{3}{ }^{-}$exports in the French Alps?

42

$43 \mathrm{NO}_{3}{ }^{-}$exports in seven streams along an altitude gradient were monitored for two 44 years.

45

$46 \mathrm{NO}_{3}{ }^{-}$isotopic composition $\left(\Delta^{17} \mathrm{O}, \delta^{15} \mathrm{~N}, \delta^{18} \mathrm{O}\right)$ was analyzed to apportion the sources. 47

48 Up to $21 \%$ of $\mathrm{NO}_{3}{ }^{-}$in montane streams and $5 \%$ in urban streams was unprocessed $49 \mathrm{NO}_{3}{ }^{-} \mathrm{atm}$.

50

51 Nitrification of atmospheric and mineralized $\mathrm{NH}_{4}{ }^{+}$was the ubiquitous main $\mathrm{NO}_{3}{ }^{-}$

52 source. 


\section{Introduction}

Atmospheric nitrogen $(\mathrm{N})$ deposition has increased 10 -fold over the past century, increasingly contributing to the global N availability (Galloway et al., 2004). Anthropogenic activities such as fossil-fuel combustion, agriculture, and fertilizers use are responsible for this increase (Fowler et al., 2015; Galloway et al., 2008; Vitousek et al., 1997), with impacts observed in remote ecosystems (Hastings et al., 2009; Holtgrieve et al., 2011; Preunkert, 2003). High N loading to the environment has been documented for many ecosystems (Aber et al., 1989; Clark et al., 2017;

Elser et al., 2009; Matson et al., 2002). To address this issue, global efforts are underway to alleviate $\mathrm{N}$ inputs into ecosystems, aiming at "minimizing the consequent harm to humans and the environment" (International Nitrogen Initiative, http://www.initrogen.org).

Nitrate concentrations, and fluxes in soils and streams have often been used to assess the $\mathrm{N}$ saturation status in watersheds (Aber et al., 1989; Baron and Campbell, 1997; Lovett and Goodale, 2011). However, N exports in stream depend on multiple parameters such as basin topography (Balestrini et al., 2013; Clow and Sueker, 2000), land-cover (Barnes et al., 2014; Williams et al., 2016) and landmanagement (Barnes and Raymond, 2010; Burns et al., 2009; Lefebvre et al., 2007). As streams integrate many processes at the watershed scale, understanding the specific sources of $\mathrm{NO}_{3}{ }^{-}$is important to (1) evaluate the respective contribution of biological and anthropogenic sources, (2) clarify the fate of deposited $\mathrm{N}$ in the environment, and (3) understand the origin and the development of $\mathrm{N}$ saturation. Mountainous ecosystems are particularly sensitive to increased $\mathrm{N}$ inputs by atmospheric deposition (Baron et al., 2000, 2005, 2011), as they are historically $\mathrm{N}$ limited (Kaye and Hart, 1997). Critical loads for these ecosystems are among the 
lowest for pristine environments (Baron et al., 2011; Bowman et al., 2006; Nanus et al., 2017), making them vulnerable to long-range transport of atmospheric $\mathrm{N}$ emitted from distant sources (Mast et al., 2014; Wasiuta et al., 2015). Atmospheric deposition of $\mathrm{N}$ has been shown to contribute significantly, either directly or indirectly, to yearround $\mathrm{NO}_{3}{ }^{-}$exports from mountainous catchments (Hundey et al., 2016; Nanus et al., 2008), typically showing a pulse at spring as soils subsurface $\mathrm{NO}_{3}{ }^{-}$reservoirs are flushed by snowmelt water (Kendall et al., 1995; Williams et al., 2009; Williams and Melack, 1991).

Atmospheric deposition is also a major source of $\mathrm{N}$ to urban areas, which receive much higher loads than adjacent environments (Bettez and Groffman, 2013; Fang et al., 2011; Hall et al., 2014; Rao et al., 2014; Templer et al., 2015). Local and regional emissions and subsequent deposition of fuel-combustion derived $\mathrm{NO}_{\mathrm{x}}$ and ammonia $\left(\mathrm{NH}_{3}\right)$ are responsible for this pattern (Galloway et al., 2004; Kean et al., 2000). $\mathrm{NO}_{x}$ compounds are oxidized into $\mathrm{NO}_{3}{ }^{-}$within hours (Beirle et al., 2011), then scavenged from the atmosphere by wet and dry deposition (Hertel et al., 2012). In the atmosphere, $\mathrm{NH}_{3}$ is in equilibrium with ammonium $\left(\mathrm{NH}_{4}{ }^{+}\right)$, the other primary component of bulk $\mathrm{N}$ deposition. Because of the particular topography of urban basins (extended impervious surface, rapid precipitation runoff), urbanization can lead to high $\mathrm{NO}_{3}{ }^{-}$exports in freshwater bodies (Groffman et al., 2004; Riha et al., 2014), with major ecological, economic and health consequences (Dodds et al., 2009).

This study aims at evaluating how atmospheric deposition of $\mathrm{N}$ is reflected in $\mathrm{NO}_{3}{ }^{-}$exports in several streams along a montane to urban gradient in the French Alps. Isotopic $\left(\Delta^{17} \mathrm{O}, \delta^{15} \mathrm{~N}, \delta^{18} \mathrm{O}\right.$ of nitrate, $\delta^{2} \mathrm{H}$ and $\delta^{18} \mathrm{O}$ of water $)$ and hydro- 
103 removal in all streams. The first hypothesis was that due to a higher contribution from

104 other sources (e.g., sewage, fertilizers) in urban areas compared to the mountains, 105 coupled with higher local atmospheric $\mathrm{N}$ inputs, total $\mathrm{NO}_{3}{ }^{-}$and atmospheric nitrate $106\left(\mathrm{NO}_{3}{ }^{-} \mathrm{atm}\right)$ exports should increase along the gradient. The second hypothesis was 107 that different $\mathrm{NO}_{3}{ }^{-}$atm export dynamics should be observed in urban streams compare 108 to montane streams, due to different hydrological drivers that need to be determined.

109 To test these hypotheses, (1) $\mathrm{NO}_{3}{ }^{-}$concentration and isotopic composition were 110 determined in six streams and one lake, ranging from $2000 \mathrm{~m}$ above sea level (a.s.l.) 111 to $200 \mathrm{~m}$ (a.s.I.) in the French Alps, (2) the annual export fluxes of $\mathrm{NO}_{3}{ }^{-}$atm and total $112 \mathrm{NO}_{3}{ }^{-}$were compared across sites along the gradient, (3) the hydrological drivers of 113 the seasonal variability in $\mathrm{NO}_{3}{ }^{-}$atm proportion were identified and (4) the additional 114 sources of $\mathrm{NO}_{3}{ }^{-}$in each watershed were determined. 


\section{Methods}

\section{$117 \quad 2.1$ Study site and selected streams}

The Romanche Valley, located in the central French Alps, spreads from the

119 Lautaret pass (2058m a.s.I.) down to Grenoble (250m a.s.I.) (Figure S1a and b). The

120 Grenoble conurbation counts around 500000 inhabitants, and is the biggest alpine

121 metropolis in France.

122 Six streams and one lake were sampled from the Lautaret pass to Grenoble,

123 draining watersheds of increasing size and with distinct geomorphic and

124 biogeographic characteristics (Table 1). Two alpine streams were sampled at

$125 \sim 2000$ m a.s.I.. These drain the South exposed side of the Lautaret pass (S-upper

126 montane, $n=157$ ) and the North exposed side ( $N$-upper montane, $n=93$ ), where for

127 the latter the stream is mainly fed by glacier melt (Figure S1c). The mid montane

128 stream $(\mathrm{n}=67$ ) was sampled at $\sim 1600 \mathrm{~m}$ a.s.l., $6 \mathrm{~km}$ down from the Lautaret pass

129 (Figure S1c). All three streams are tributaries of Romanche (lower montane stream,

$130 \mathrm{n}=127$ ) that was sampled $15 \mathrm{~km}$ down from the Lautaret pass at $\sim 1000 \mathrm{~m}$ a.s.l., before

131 ending in Chambon lake (Figure S1d). The lake ( 900m a.s.l., $\mathrm{n}=29)$ is an artificial

132 reservoir managed by the French national electricity company (EDF), $21 \mathrm{~km}$ down

133 from the Lautaret pass. The two urban streams ( 210 $\mathrm{m}$ a.s.I.) were located, for one,

134 upstream from Grenoble main urbanized area (upper urban stream, $n=48$ ) and, for

135 the other, downstream (lower urban stream, $\mathrm{n}=45$ ), and were separated by $8 \mathrm{~km}$

136 (Figure S1e). The lower urban stream waters are derived from the lower montane

137 stream (and the lake). The upper urban stream, Isère, has surface water from

138 another alpine valley. The upper urban stream flows through residential areas,

139 gardens, and some arable fields prior to the sampling location whereas the lower 
140 urban site abuts industrial developments as well as residential neighborhoods

141 (Dutordoir, 2014).

142

\subsection{Deposition and streams sampling, discharge and conductivity}

Atmospheric wet and dry deposition samples were collected using a WADOS

Kroneis collector (GmbH Austria) at the S-upper montane site from April 2016 to April

2017. A moving lid - connected to heated moisture sensor - ensured the separated of the Lautaret pass Alpine Research Station ( 210 m a.s.I.),

$150 \mathrm{https://www.jardinalpindulautaret.fr)} \mathrm{to} \mathrm{reduce} \mathrm{the} \mathrm{impact} \mathrm{of} \mathrm{ground} \mathrm{turbulence} \mathrm{and}$ 151 input of soil particles. Samples were collected approximately every three weeks. 152 Precipitation samples were kept at $4^{\circ} \mathrm{C}$ during the sampling period, then frozen until 153 further analysis. After exposure to the atmosphere, the dry deposition funnel was 154 rinsed with $500 \mathrm{~mL}$ of MilliQ water, and the sample was stored at $-20^{\circ} \mathrm{C}$.

155 Stream and lake water was sampled at all sites according to the Niwot Ridge 156 LTER protocol (Williams and Melack, 1991). In short, samples (total $n=566$ ) were collected manually in $1 \mathrm{~L}$ Nalgene bottles, previously washed 3 times with MilliQ water $158\left(18.2 \mathrm{M} \Omega \cdot \mathrm{cm}^{-1}\right.$ at $\left.25^{\circ} \mathrm{C}\right)$ and rinsed three times with stream water before collection. 159 All samples were then kept at $-20^{\circ} \mathrm{C}$ until further treatment. Water samples were 160 collected on a weekly to monthly basis from January 2015 to December 2016, with 161 increased sampling frequency in two of the upper tributaries from April to May 2016. 162 During this intensive sampling period, water was collected using three automatic 163 water samplers (Teledyne ISCO ${ }^{\circledR} 3700$ ) every two or three hours at the S-upper and 164 lower montane sites. Water conductivity, shown to be a good proxy of discharge 
165 (Weijs et al., 2013), and water temperature were also intensively monitored (2

166 minutes stepwise) over that period using CTD-Diver ${ }^{\circledR}$ sensors. Spring sampling was sporadic in the $\mathrm{N}$-upper montane site because of persistent snow cover. Winter sampling was not possible at the lake site as it was frozen.

Discharge data was obtained from the national discharge-monitoring network

170 (Banque Hydro) or measured every hour for both lower montane and urban site.

171 Stream stage at the upper urban site was monitored every 30 minutes using water

172 level gauge sensor $\left(\mathrm{OTT}^{\circledR}\right)$ at Grenoble Campus station (more details in Mano, 2008;

173 Némery et al., 2013). Discharge was estimated from stage measurements by using 174 rating curve (water level vs discharge) (Némery et al., 2013). Continuous discharge

175 could not be measured at the upper and mid montane sites due to the torturous

176 nature of the streams. Precipitation data were obtained from the Alpine Mountain

177 Meteorological Office Network (www.romma.fr) at the upper montane site and using 178 a rain gauge (Précis Mécaniques ${ }^{\circledR}$ ) on a building roof of the Grenoble Campus, close 179 to the upper urban site.

180

\subsection{Chemical and isotopic analysis}

All stream and deposition samples were left to unfreeze at ambient temperature prior to being filtered using $0.45 \mu \mathrm{m}$ Whatman $\mathrm{GD} / \mathrm{X}$ syringe filters linked

184 to a peristaltic pump. They were subsequently analyzed for ion concentrations

$185\left(\left[\mathrm{NH}_{4}^{+}\right],\left[\mathrm{NO}_{3}{ }^{-}\right],\left[\mathrm{SO}_{4}{ }^{2-}\right],\left[\mathrm{Cl}^{-}\right],\left[\mathrm{Ca}^{2+}\right]\right)$ using a colorimetric technique (Gallery Plus, 186 Thermo Fisher Scientific, Waltham, Massachusetts, USA). An analytical error $<0.01$ $\mathrm{mg} \mathrm{L}^{-1}$ was determined for all ions based on the standard deviation of commercial control solutions (ThermoFisher ${ }^{\circledR}$ ) analyzed as unknowns. Major ions such as sulfate and calcium and chloride are often used as hydro-chemical tracers of water 
190 flowpaths or water sources (Briand, 2014; Devito et al., 2000; Hall et al., 2016;

191 Stoewer et al., 2015), and were measured to identify the dominating hydrological 192 regimes in the studied sites.

193 All samples were concentrated on an anionic resin (0.6mL AG 1-X8 resin, $\mathrm{Cl}^{-}$-

194 form, Bio-Rad) with recovery efficiency over 98.5\% (Erbland, 2011) and eluted with

$19510 \mathrm{~mL}$ of a $1 \mathrm{M} \mathrm{NaCl}$ solution for isotopic analysis (Templer and Weathers, 2011).

196 Isotopic analyses of $\mathrm{NO}_{3}{ }^{-}\left(\Delta^{17} \mathrm{O}, \delta^{18} \mathrm{O}\right.$ and $\left.\delta^{15} \mathrm{~N}\right)$ were conducted on an MAT 253

197 IRMS using an adapted version of the denitrifier method (Kaiser et al., 2007; Morin et

198 al., 2008). More details about the experimental setup can be found elsewhere (SI

199 Text). The analytical errors - calculated as the standard deviation of the residuals

200 from the linear regression between raw data of the reference standards (USGS 32,

201 USGS 34 and USGS 35) and their accepted values - were $\pm 0.4,1.5$ and $0.3 \%$ for

$202 \Delta^{17} \mathrm{O}, \delta^{18} \mathrm{O}$ and $\delta^{15} \mathrm{~N}$ of $\mathrm{NO}_{3}{ }^{-}$, respectively. Slopes and intercepts of the linear

203 regressions are then used to convert raw sample data into calibrated values

204 (VSMOW scale for $\mathrm{O}$ isotopes, and N2-air scale for $\mathrm{N}$ isotopes).

205 A subset of stream, rain, and snow samples (collected in winter 2015-2016)

206 were sent for $\delta^{2} \mathrm{H}$ and $\delta^{18} \mathrm{O}$ analyses on a Picarro L2130-i at the Laboratoire des

207 Sciences et du Climat (LSCE) in Paris, France. The analytical error - inferred from

208 the replicate analysis of internal standards calibrated against V-SMOW2 et V-SLAP2

209 standards - was \pm 0.7 and $0.2 \%$ for $\delta^{2} \mathrm{H}$ and $\delta^{18} \mathrm{O}$ of $\mathrm{H}_{2} \mathrm{O}$, respectively.

$2112.4 \mathrm{NO}_{3}{ }^{-}$sources apportionment

212 A number of previous studies have used the dual isotope approach $\left(\delta^{18} \mathrm{O}\right.$ and

$213 \delta^{15} \mathrm{~N}$ of $\mathrm{NO}_{3}{ }^{-}$) to track the spatio-temporal variability of sources contribution to $\mathrm{NO}_{3}{ }^{-}$

214 pools in a large variety of environmental matrixes (Campbell et al., 2002; Durka et al., 
215 1994; Elliott et al., 2009; Yang and Toor, 2016). Biochemical processes such as

216 denitrification or assimilation have also been shown in laboratory experiments to

217 distinguishably enrich residual $\mathrm{NO}_{3}{ }^{-}$in heavier isotopes, here ${ }^{15} \mathrm{~N}$ and ${ }^{18} \mathrm{O}$ (Granger et

218 al., 2004, 2010; Treibergs and Granger, 2017), although this enrichment can be

219 diluted by newly nitrified $\mathrm{NO}_{3}{ }^{-}$with low $\mathrm{N}$ and $\mathrm{O}$ isotopic values (Granger and

220 Wankel, 2016; Mayer et al., 2002). Environmental studies also reported characteristic

$221 \mathrm{NO}_{3}{ }^{-}$isotopic enrichment for denitrification (Clément et al., 2003; Fang et al., 2015;

222 Wexler et al., 2014), assimilation (Emmerton et al., 2001; Estrada et al., 2017; X.-Y.

223 Liu et al., 2013) or photolysis (Frey et al., 2009; Shi et al., 2015; Ye et al., 2016).

224 However, the isotopic fingerprint of biological processes can lead to inaccurate $\mathrm{NO}_{3}{ }^{-}$

225 source apportionment in some cases, especially in delineating the respective

226 contribution of the microbial and the atmospheric sources (Michalski et al., 2004;

227 Riha et al., 2014; Rose et al., 2015a).

228 In the past few years, a growing number of studies have used an isotopic

229 particularity of $\mathrm{NO}_{3}{ }^{-}$atm to quantify the contribution of atmospheric deposition to

230 terrestrial N pools (Costa et al., 2011; Hundey et al., 2016; Tsunogai et al., 2014).

$231 \mathrm{NO}_{3}{ }^{-}$atm is enriched in ${ }^{17} \mathrm{O}$ due to its production pathways (i.e., oxidation of $\mathrm{NO}_{x}$ by

$232 \mathrm{O}_{3}$ ), showing a deviation from the Terrestrial Fractionation Line (Thiemens, 2006).

$233 \Delta \Delta^{17} \mathrm{O}$ is a quantification of this deviation, calculated as $\Delta^{17} \mathrm{O}=\delta^{17} \mathrm{O}-0.52{ }^{*} \delta^{18} \mathrm{O}$ in

234 the present work. $\Delta^{17} \mathrm{O}$ value of $\mathrm{NO}_{3}{ }^{-}$atm generally ranges between 20 and $35 \%$ in

235 temperate latitudes (Morin et al., 2009; Savarino et al., 2007), whereas $\Delta^{17} \mathrm{O}$ value of

$236 \mathrm{NO}_{3}{ }^{-}$from all other sources (industrial fertilizers, nitrification) or of biologically

237 processed $\mathrm{NO}_{3}{ }^{-}$atm, is $0 \%$ (Michalski et al., 2004, 2015). In this study, these two

238 distinct $\Delta^{17} \mathrm{O}$ values were used as end-members in a simple mixing model to quantify

239 unprocessed $\mathrm{NO}_{3}{ }^{-}$atm proportion $\left(f_{\text {atm }}\right)$ in streams, according to Michalski et al. 


$$
f_{\text {atm }}=\left(\Delta^{17} \mathrm{O}-\mathrm{NO}_{3}^{-} \text {sample } / \Delta^{17} \mathrm{O}-\mathrm{NO}_{3}^{-} \text {atm }\right)
$$

$f_{\text {atm) }}$ can be used to remove the isotopic influence of $\mathrm{NO}_{3}{ }^{-}$atm on samples, and allow

246 for a better interpretation of biological processes that affect $\delta^{15} \mathrm{~N}$ and $\delta^{18} \mathrm{O}$ (Dejwakh 247 et al., 2012; Michalski et al., 2004; Riha et al., 2014; Tsunogai et al., 2010). $\delta^{18} \mathrm{O}$ vs $248 \delta^{15} \mathrm{~N}$ plots have been intensively used to evaluate sources of $\mathrm{N}$ and potential 249 processes (denitrification, assimilation) in the environment (Burns et al., 2009; Durka 250 et al., 1994; Griffiths et al., 2016; Kendall et al., 1995; X.-Y. Liu et al., 2013).

251 However, because of strongly distinct $\delta^{18} \mathrm{O}-\mathrm{NO}_{3}{ }^{-}$atm values compared to $\delta^{18} \mathrm{O}-\mathrm{NO}_{3}{ }^{-}$ter, 252 even a low $f_{\text {atm }}$ can lead to scatter in a dual-isotope plot. Removing the atmospheric $253 \delta^{15} \mathrm{~N}$ and $\delta^{18} \mathrm{O}$ components from environmental samples leads to an easier 254 assessment of biological processes, such as assimilation or denitrification. This 255 isotope correction was applied on the samples using the isotopic mass balances from 256 Riha et al. (2014):

$$
\delta^{18} O_{\text {ter }}=\left(\delta^{18} O_{\text {sample }}-\delta^{18} O_{a t m}{ }^{*} f_{\text {atm }}\right) / f_{\text {ter }}
$$

260

$$
\delta^{15} N_{t e r}=\left(\delta^{15} N_{\text {sample }}-\delta^{15} N_{a t m}^{*} f_{a t m}\right) / f_{t e r}
$$

$262 \delta^{15} \mathrm{~N}_{a t m}$ and $\delta^{18} \mathrm{O}_{a t m}$ were inferred from $\mathrm{NO}_{3}{ }^{-}$in wet and dry atmospheric deposition 263 (see section 3.2). A formal propagation of uncertainty was performed to assess the 264 error associated with individual values of $f_{\text {atm }}, \delta^{18} \mathrm{O}-\mathrm{NO}_{3}{ }_{\text {ter }}^{-}$and $\delta^{15} \mathrm{~N}^{-\mathrm{NO}_{3}}{ }_{\text {ter. }}$. Although 
265 the error associated with individual values can be large (Figure S2), averaging across

266 samples throughout the year results in a robust estimate of annual $f_{\text {atm }}, \delta^{18} \mathrm{O}-\mathrm{NO}_{3}{ }^{-}$ter 267 and $\delta^{15} \mathrm{~N}^{-\mathrm{NO}_{3}}{ }_{\text {ter }}^{-}$values (Dejwakh et al., 2012).

268

2.5 Fluxes of $\mathrm{NO}_{3}^{-}$and $\mathrm{NO}_{3}^{-}$atm

$\mathrm{NO}_{3}^{-}$yields $\left(\mathrm{F}_{\mathrm{m}}\right.$ in $\left.\mathrm{kg}-\mathrm{N} \mathrm{w}^{-1}\right)$ were calculated at each site - when possible - on

a weekly basis using the mean weekly discharge $\left(Q_{m}\right.$ in $\left.\mathrm{m}^{3} \mathrm{~s}^{-1}\right)$ and instantaneous concentrations $\left(\left[\mathrm{NO}_{3}^{-}\right]_{\mathrm{i}}\right.$ in $\left.\mathrm{mg}-\mathrm{N} \mathrm{L}^{-1}\right)$, as follows:

273

274

(Eq.4)

$$
F_{m}=Q_{m}^{*}\left[\mathrm{NO}_{3}^{-}\right]_{i}
$$

275

276 Total specific annual stream loads of $\mathrm{NO}_{3}{ }^{-}\left(\mathrm{F}_{\text {tot }}\right.$ in $\left.\mathrm{kg}-\mathrm{N} \mathrm{ha}{ }^{-1} \mathrm{yr}^{-1}\right)$ were calculated as 277 the annual sum of weekly $\mathrm{NO}_{3}{ }^{-}$exports during the study period (2015 and 2016), as 278 follows:

279

280

(Eq.5)

$$
\mathbf{F}_{\text {tot }}=\left(\sum_{\mathrm{m}} \mathrm{Fm}\right) /(\text { watershed area })
$$

281

282 Finally, total annual $\mathrm{NO}_{3}{ }^{-}$atm loads $\left(\mathrm{F}_{\text {atm }}\right)$ were calculated for each year by multiplying 283 the total annual stream yield of $\mathrm{NO}_{3}{ }^{-}\left(\mathrm{F}_{\text {tot }}\right)$ by the discharge-weighted annual mean $284 f_{\text {atm }}$ in the stream (see Eq. 1), according to Tsunogai et al. $(2014,2010)$ :

285

286

(Eq. 6)

$$
F_{\text {atm }}=F_{\text {tot }}{ }^{*} f_{\text {atm }}
$$

288 When $\left[\mathrm{NO}_{3}{ }^{-}\right]$or $\Delta^{17} \mathrm{O}$ values were not available for a given date $(n=4,2$ and 2 for the 289 lower montane, upper urban and lower urban streams, respectively), they were 
290 replaced by the mean $\left[\mathrm{NO}_{3}{ }^{-}\right]$or $\Delta^{17} \mathrm{O}-\mathrm{NO}_{3}{ }^{-}$values measured on the previous and the 291 following dates, to capture temporal variations due to hydrological events. Note that 292 the use of instantaneous $\left[\mathrm{NO}_{3}{ }^{-}\right]$to calculate weekly streams $\mathrm{NO}_{3}{ }^{-}$loads might over or 293 under estimate the real $\mathrm{NO}_{3}^{-}$yield in streams.

294

\subsection{Statistical analysis}

A Mann-Whitney test was applied to surface water data to determine whether mean concentrations and isotopic values were significantly different between streams. A Spearman test was applied to evaluate the correlation between stream water parameters (typically $\Delta^{17} \mathrm{O}, \delta^{18} \mathrm{O}, \delta^{15} \mathrm{~N}$ and ion concentrations). Differences and correlations were considered significant when the $p$ value was $\leq 0.05$. All

301 statistical analyses were conducted using R software (v3.2.3). Unless specified otherwise, the uncertainty accompanying the mean values is the standard deviation.

\section{Results}

\subsection{Precipitation and discharge} Cumulated precipitation was 537 and $609 \mathrm{~mm}$ in 2015 and 804 and $740 \mathrm{~mm}$ in 2016 at the upper montane and the urban sites, respectively. Discharge at the lower montane site reflects a snowmelt influenced hydrological regime. It peaked up to 30

$309 \mathrm{~m}^{3} \mathrm{~s}^{-1}$ in spring, and was significantly higher from April to October compared to the

310 rest of the year. Discharge at both urban sites was consistent with a hydrological

311 regime driven by snowmelt in spring-summer (main maximum), and rainfall in autumn

312 (secondary maximum), a dual contribution similar to what was obtained in the

313 Colorado Front Range (Cowie et al., 2017). At the upper urban site, discharge 314 peaked at $900 \mathrm{~m}^{3} \mathrm{~s}^{-1}$, whereas maximum discharge was $300 \mathrm{~m}^{3} \mathrm{~s}^{-1}$ at the lower 
315 urban site, a difference due to the streams draining two distinct watersheds (Figure 316 S3).

\subsection{Comparison of dissolved solutes across sites}

Solutes concentration varied by up to 3 orders of magnitude among precipitation and streams samples (Table S2 and Figure 1). $\left[\mathrm{NH}_{4}{ }^{+}\right]$was low in both dry and wet deposition at the S-upper montane site, and mostly (>90\%) under the detection limit $\left(<0.02 \mathrm{mg} \mathrm{L}^{-1}\right)$ in all streams. $\left[\mathrm{NO}_{3}^{-}\right]$was significantly higher in rain samples compared to stream samples. The highest annual mean $\left[\mathrm{NO}_{3}{ }^{-}\right]$was

324 measured in the lower urban stream $\left(1.4 \pm 0.5 \mathrm{mg} \mathrm{L}^{-1}\right)$ and the lowest in the S-upper 325 montane stream $\left(0.2 \pm 0.2 \mathrm{mg} \mathrm{L}^{-1}\right) .\left[\mathrm{NO}_{3}^{-}\right]$at the $\mathrm{N}$-upper montane, mid montane, 326 lower montane and upper urban sites were not statistically different $(1.4 \pm 1.3,1.1 \pm$ $0.6,1.0 \pm 0.6$ and $1.1 \pm 0.4 \mathrm{mg} \mathrm{L}^{-1}$, respectively). $\left[\mathrm{SO}_{4}{ }^{2-}\right]$ and $\left[\mathrm{Ca}^{2+}\right]$ were both very 328 low in precipitation relative to streams. The S-upper montane stream exhibited the 329 highest annual mean $\left[\mathrm{SO}_{4}{ }^{2-}\right]$ and $\left[\mathrm{Ca}^{2+}\right]\left(98.5 \pm 39.5\right.$ and $44.5 \pm 18.2 \mathrm{mg} \mathrm{L}^{-1}$, 330 respectively), followed by the upper urban stream $\left(74.1 \pm 26.9\right.$ and $35.2 \pm 13.1 \mathrm{mg} \mathrm{L}^{-}$

331 , respectively), and the lowest concentrations were measured at the N-upper 332 montane site $\left(22.1 \pm 35.9\right.$ and $16.5 \pm 16.0 \mathrm{mg} \mathrm{L}^{-1}$, respectively). [ $\left.\mathrm{Cl}^{-}\right]$was very low in 333 precipitation samples and in most montane streams (mean values all $<3 \mathrm{mg} \mathrm{L}^{-1}$ ), 334 respectively. Higher annual mean $\left[\mathrm{Cl}^{-}\right]$were measured in the urban streams $(4.7 \pm$ 3351.8 and $16.6 \pm 12.3 \mathrm{mg} \mathrm{L}^{-1}$ for the upper and lower urban stream, respectively).

\subsection{Isotopic composition of $\mathrm{NO}_{3}{ }^{-}$in precipitation and streams}


340 widely monitored at temperate latitudes (Beyn et al., 2014; Freyer, 1991; Mara et al.,

341 2009). Mean and associated standard deviation of $\Delta^{17} \mathrm{O}-\mathrm{NO}_{3}{ }^{-}$in precipitation and dry

342 deposition were $26.4 \pm 3.2$ and $24.7 \pm 3.5 \%$, respectively. These values are in the

343 same range as previously reported data for $\Delta^{17} \mathrm{O}-\mathrm{NO}_{3}{ }^{-}$atm $($Costa et al., 2011;

344 Michalski et al., 2004; Tsunogai et al., 2010, 2016). The mean $\Delta^{17} \mathrm{O}$ value for total

345 deposition was $25.6 \pm 3.3 \%$, and was used to quantify the atmospheric component

346 of $\mathrm{NO}_{3}{ }^{-}$pools in streams (see section 2.4, Eq. 1). Mean annual total $\delta^{18} \mathrm{O}-\mathrm{NO}_{3}{ }^{-}$atm

347 (70.8 $\pm 7.2 \%)$ and $\delta^{15} \mathrm{~N}^{-\mathrm{NO}_{3}}{ }^{-} \mathrm{atm}(-4.8 \pm 5.9 \%)$ are also consistent with a reservoir of

348 exclusively $\mathrm{NO}_{3}{ }^{-}$atm (Kendall et al., 2007), and these values were used to correct

349 samples from their atmospheric $\delta^{18} \mathrm{O}$ and $\delta^{15} \mathrm{~N}$ components (see section 2.4, Eq.2

350 and 3).

$351 \quad$ Significantly higher annual mean $\Delta^{17} \mathrm{O}-\mathrm{NO}_{3}{ }^{-}$was measured in montane

352 streams compared to urban streams, with the exception of the mid montane site (1.0

$353 \pm 0.7 \%$ ), which exhibited the lowest values (Figure $2 a$ ). Both upper and lower urban,

354 along with the mid montane streams were also characterized by the highest annual

355 mean $\delta^{15} \mathrm{~N}^{-N_{3}}{ }_{3}^{-}(3.7 \pm 1.0 \%, 4.9 \pm 5.6 \%$ and $4.0 \pm 2.0 \%$, respectively) (Figure $2 \mathrm{c}$ ).

356 The lake, fueled by the lower montane stream, presented the highest annual mean

$357 \Delta^{17} \mathrm{O}-\mathrm{NO}_{3}{ }^{-}(5.1 \pm 1.8 \%)$ and $\delta^{18} \mathrm{O}-\mathrm{NO}_{3}{ }^{-}\left(8.6 \pm 6.2 \%\right.$, and the lowest $\delta^{15} \mathrm{~N}-\mathrm{NO}_{3}{ }^{-}(-0.2$

$358 \pm 2.4 \%$ ) (Figure $2 \mathrm{a}, \mathrm{b}$ and $\mathrm{c}$ ). It must be stressed out again that the lake was only

359 sampled when unfrozen (i.e., late spring, summer and autumn), potentially biasing

$360 \mathrm{NO}_{3}{ }^{-}$mean isotopic values at this site. 
Seasonal variations of stream $\mathrm{NO}_{3}{ }^{-}$isotopes and corresponding $f_{\text {atm }}$ are shown in Figure 3. The three montane streams followed a similar pattern of seasonal variations in 2015 and 2016. At the S-upper montane site, $\Delta^{17} \mathrm{O}-\mathrm{NO}_{3}{ }^{-}$and $\delta^{15} \mathrm{~N}-\mathrm{NO}_{3}{ }^{-}$ were significantly negatively correlated, with brief but high $\Delta^{17} \mathrm{O}-\mathrm{NO}_{3}^{-}$peaks in spring, followed by a slow but continuous increase peaking late summer/beginning of autumn. At the N-upper site, a saw tooth pattern in summer and autumn occurred right after a small but temporally wider increase at snowmelt, in early summer. $\Delta^{17} \mathrm{O}$ $\mathrm{NO}_{3}{ }^{-}$and $\delta^{15} \mathrm{~N}-\mathrm{NO}_{3}{ }^{-}$in the mid montane stream presented little variations throughout the seasons, apart from a raise in $\delta^{15} \mathrm{~N}-\mathrm{NO}_{3}{ }^{-}$in spring/summer 2016. $\Delta^{17} \mathrm{O}-\mathrm{NO}_{3}{ }^{-}$and $\delta^{15} \mathrm{~N}-\mathrm{NO}_{3}{ }^{-}$were significantly negatively correlated in the lower montane stream and in the lake, with significantly higher $\Delta^{17} \mathrm{O}-\mathrm{NO}_{3}{ }^{-}$from April to October - relative to the rest of the year - in a very similar way to discharge (Figure S3). Finally, $\Delta^{17} \mathrm{O}-\mathrm{NO}_{3}{ }^{-}$ and $\delta^{15} \mathrm{~N}-\mathrm{NO}_{3}$ - were not correlated and did not vary much in urban streams, except for some occasional high $\delta^{15} \mathrm{~N}$ peaks in spring and winter 2015 at the lower urban site.

\section{Discussion}

\section{1 $\mathrm{NO}_{3}{ }^{-}$exports in streams}

\section{$\underline{4.1 .1\left[\mathrm{NO}_{3}{ }_{3}\right] \text { across the altitude gradient }}$}

There were little differences in streams $\left[\mathrm{NO}_{3}{ }^{-}\right]$along the elevation gradient despite an expected higher contribution from anthropogenic activities to streams $\mathrm{N}$ pool closer to urbanized areas (Groffman et al., 2004; Tsunogai et al., 2016). The 0.2-1.4 $\mathrm{mg} \mathrm{L}^{-1}$ mean $\left[\mathrm{NO}_{3}{ }^{-}\right]$range at the montane sites is consistent with the 0.6-1.6 $\mathrm{mg} \mathrm{L}^{-1}$ range in other Alpine valleys (reviewed in Balestrini et al., 2013), and the 0.9$1.5 \mathrm{mg} \mathrm{L}^{-1}$ range in elevated sites of the Colorado Front Range (Baron and Campbell, 1997; Campbell et al., 1995). The N-upper montane site had a much wider $\left[\mathrm{NO}_{3}{ }^{-}\right]$ 
389

390

range than the S-upper montane site, which is attributed to glacier melt influence (Barnes et al., 2014; Williams et al., 2007). [NO $\left.{ }_{3}^{-}\right]$in urban streams was low when compared to other concentrations measured in urban settings, such as the Tucson basin where values up to $62 \mathrm{mg} \mathrm{L}^{-1}$ were determined (Dejwakh et al., 2012) or up to $26 \mathrm{mg} \mathrm{L}^{-1}$ in the Gwynns Falls watershed (Groffman et al., 2004).

\section{$\underline{4.1 .2 \mathrm{NO}_{3}}={ }^{-}{ }^{a t m}$ contribution to total $\mathrm{NO}_{3}=$}

Atmospheric deposition contributed significantly more to $\mathrm{NO}_{3}{ }^{-}$pool in streams at the montane sites relative to the urban sites - exception being the mid montane site (Figure 2). The Chambon lake showed the highest $f_{\text {atm, }}$ although it is possible that sampling of this reservoir exclusively in summer resulted in a biased estimate of mean annual $\mathrm{NO}_{3}{ }^{-}$atm. High $\mathrm{NO}_{3}{ }^{-}$atm inputs in montane streams (up to $47 \%$ ) clearly outline the influence of the melting snowpack releasing its load of atmospheric nitrate (see section 4.2.1), as widely reported elsewhere (Kendall et al., 1995; Ohte et al., 2004; Pellerin et al., 2012; Tsunogai et al., 2014, 2016). The mid montane stream exported the lowest proportion of $\mathrm{NO}_{3}{ }^{-}$atm. Smoother topography gradient on this watershed (slopes are 17\%, Table 1) can account for this by impeding direct runoff to stream during hydrological extremes (e.g., snowmelt), thus exerting a strong control over $\mathrm{NO}_{3}{ }^{-}$isotopic values in the stream (Balestrini et al., 2013; Clow and Sueker, 2000). In addition, a smoother topography gradient also drives a higher $\mathrm{NO}_{3}{ }^{-}$atm residence time in soils that would overwrite its $\Delta^{17} \mathrm{O}$ signature when recycled by microorganisms. The low $f_{\text {atm }}$ in urban streams is dissimilar to others results that have shown an increasing $f_{\text {atm }}$ in streams along an urbanization gradient (Riha et al., 2014), or high $\mathrm{NO}_{3}{ }^{-}$atm inputs in urban runoff (Yang and Toor, 2016). In urban areas, the combination of more impervious surface area coupled to higher atmospheric 
414 deposition inputs is a strong driver that was expected to promote a higher proportion

415 of $\mathrm{NO}_{3}{ }^{-}$atm in urban streams, relative to montane sites. Indeed, $\mathrm{NO}_{3}{ }^{-}$atmospheric

416 concentrations in Grenoble's urban area are 10 to 100 times higher than atmospheric

417 concentrations observed at the Lautaret pass (Bourgeois, 2017; Tomaz et al., 2017),

418 which should have promoted higher $\mathrm{NO}_{3}{ }^{-}$atm loads in urban streams. However, higher

419 total $\mathrm{NO}_{3}{ }^{-}$atm loads are calculated at the lower montane site where $\mathrm{NO}_{3}{ }^{-}$atm

420 represented $21 \%$ of the total annual $\mathrm{NO}_{3}{ }^{-}$exports (Table 2 ).

421 Elevated $\mathrm{N}$ deposition in the Alps - also illustrated by higher $\left[\mathrm{NO}_{3}^{-}\right]$in wet and

422 dry deposition compared to streams (Table S2) - is a well-documented phenomenon

423 (Kirchner et al., 2014; Rogora et al., 2006). Sustained nitrogen deposition in addition

424 to the steep slopes of the lower montane watershed (Table 1) can account for the

425 higher total $\mathrm{NO}_{3}{ }^{-}$atm flux at the montane site. Grenoble conurbation land cover is

426 mainly constituted of forest and lower vegetation (64\%) followed by agricultural fields

427 (24\%), and impervious surfaces (10\%) are only a minor surface occupation (UE-

428 SOeS, CORINE Land Cover, 2006). $\mathrm{NO}_{3}{ }^{-}$atm inputs are thus likely to move to multiple

429 sinks, be biologically recycled or lost via different processes (e.g., denitrification,

430 photolysis (Clément et al., 2003; Ye et al., 2016)) before being collected by the urban

431 streams (Rao et al., 2014). Furthermore, a strong decoupling between atmospheric $\mathrm{N}$

432 deposition and urban soils $\mathrm{N}$ cycling has recently been proposed, pointing at a

433 distinct urban biogeochemical $\mathrm{N}$ cycle - that entails that land-management practice,

434 not $\mathrm{N}$ deposition, is the ultimate driver of $\mathrm{N}$ cycling - and that would need further

435 investigation (Decina et al., 2017). Additionally, in France urban rainwater and

436 domestic wastewater are traditionally collected in the same pipe system before being

437 purified in a sewage treatment plant downstream of the cities. This would also limit

438 direct rainwater runoff to the streams, as illustrated by the statistically similar $\left[\mathrm{NO}_{3}{ }^{-}\right]$in 
439

urban streams compared to montane streams (Figure 1). One, or a combination of

440 several of these factors would lower $\mathrm{NO}_{3}{ }^{-}$atm exports in urban streams, even lower

441 than montane streams $\mathrm{NO}_{3}{ }^{-}$atm exports in this case. Therefore, the low $f_{\text {atm }}$ in urban

442 streams certainly reflects the recycling and replacement of $\mathrm{NO}_{3}^{-}$atm by terrestrial $\mathrm{NO}_{3}{ }^{-}$

443 sources along the smoother topography gradient, in a similar way to the mid-

444 montane stream.

445

446

447

448

449

450

451

452

453

454

455

456 fueled by glacier melt, leading to higher $\left[\mathrm{NO}_{3}{ }^{-}\right]$than its southern counterpart by 1

457 order of magnitude (Figure 1). This is a consequence of the permafrost thawing at

458 that site (Bodin et al., 2009), thus increasing nitrification and/or mobilization of stored

459 N from disturbed soils (Barnes et al., 2014; Hood and Scott, 2008; Louiseize et al.,

460 2014). Occasional higher $f_{\text {atm }}$ at the $\mathrm{N}$-upper site are triggered by rainstorm events

461 (Figure S3). The lower montane stream and the lake had very similar seasonal

462 variations of $\Delta^{17} \mathrm{O}-\mathrm{NO}_{3}{ }^{-}$, featuring the gradual melting of upstream snowpack

463 throughout the growing season (May to October). The mid montane and the urban 
464 streams showed no marked seasonal variation, because of the buffering effect of

465 soils and the higher $\mathrm{N}$ cycling rates inherent to more intensive land management 466 treatments that prevented $\mathrm{NO}_{3}{ }^{-}$atm inputs to streams (Table 1).

\section{$\underline{4.2 .2}$ Groundwater and surface runoff respective influence $\mathrm{NO}_{3}={ }^{a t m} \underline{\text { proportion in }}$}

\section{9 streams}

Significant correlations between rock-derived solutes $\left(\mathrm{SO}_{4}{ }^{2-}\right.$ and $\left.\mathrm{Ca}^{2+}\right)$ in all

471 streams (Figure S4) indicate groundwater contribution to streams as a unifying

472 feature along the montane to urban gradient. Varying concentrations of rock-derived

473 solutes are in good agreement with the geologic characteristics of each watershed

474 (i.e., highest concentrations in the S-upper montane and the upper urban streams

475 draining calcareous basins, lowest concentrations in the $\mathrm{N}$-upper montane stream

476 draining a less erodible bedrock, see Table 1 and Figure 1). In this study, year-round

477 detectable $\Delta^{17} \mathrm{O}-\mathrm{NO}_{3}{ }^{-}$translate the continuous $\mathrm{NO}_{3}{ }^{-}$atm exports in all streams (Figure

478 3), even during baseflow when streams are mostly fueled by groundwater. Most

479 studies focusing on $\mathrm{NO}_{3}{ }^{-}$dynamics in runoff reported $\mathrm{NO}_{3}{ }^{-}$atm only during stormflow or

480 snowmelt periods (Burns et al., 2009; Campbell et al., 2002; Pellerin et al., 2012).

481 However, these studies used the dual isotope approach (i.e., $\delta^{18} \mathrm{O}$ and $\delta^{15} \mathrm{~N}$ of $\mathrm{NO}_{3}{ }^{-}$),

482 which does not account accurately for $\mathrm{NO}_{3}{ }^{-}$atm in streams compared to the $\Delta^{17} \mathrm{O}$

483 tracer (Michalski et al., 2004; Rose et al., 2015a). In a growing body of work using $484 \Delta^{17} \mathrm{O}-\mathrm{NO}_{3}{ }^{-}$in streams, $\mathrm{NO}_{3}^{-}$atm presence during baseflow is a unifying feature (Rose 485 et al., 2015a; Sabo et al., 2016; Tsunogai et al., 2016). In all these studies, $f_{\text {atm }}$ 486 ranged from 1-12\% in baseflow, except for a coniferous watershed in West Virginia, 487 which led to $f_{\text {atm }}$ of $54 \%$ in stream, due to low sampling resolution $(n=4)$. Here, $f_{\text {atm }}$ 488 ranged from $1-20 \%$ (with a median associated error of $3 \%$, Figure S2) in all streams 
489

during the dormant season (in grey, Figure 3), somewhat higher than the literature

490 data range - because of the extended influence of snowmelt in mountainous sites

491 during the growing season. The high $\Delta^{17} \mathrm{O}-\mathrm{NO}_{3}{ }^{-}$peaks at the S-upper montane site in

492 March 2015 are due to a shorter winter this year.

493 However, even if groundwater contributed at all sites to streams water, its

494 influence on streams ionic exports had most impact in the urban reaches. No or near

495 static correlations between either $\mathrm{NO}_{3}{ }^{-}$isotopes or conservative ions and discharge 496 (Figure 4) imply that a geochemically equilibrated groundwater reservoir dominates 497 stream exports at the urban sites, instead of surface runoff (Hall et al., 2016). Oppositely, $\Delta^{17} \mathrm{O}-\mathrm{NO}_{3}{ }^{-}$increased significantly with discharge at the lower montane 499 site, highlighting the influence of snowmelt on $\mathrm{NO}_{3}{ }^{-}$atm exports (Figure 4a).

500 Decreasing weathering products concentrations with high flow also evidence the 501 decreasing contribution of groundwater towards more surficial water at snowmelt 502 (Figure $4 d$ and f). No significant correlation of $\left[\mathrm{NO}_{3}{ }^{-}\right]$with discharge in any stream 503 implies a homogenized $\mathrm{NO}_{3}{ }^{-}$pool in groundwater reservoirs by infiltrated snowmelt 504 inputs. In line with this hypothesis, a dual isotope plot of water illustrates that 505 snowmelt more than rain fueled the streams, even down to the outskirts of Grenoble 506 (Figure S5). Other studies also reported similar findings of underground reservoirs 507 fed by snowmelt in mountains vicinity (Brooks et al., 1999; Hall et al., 2016; Williams 508 et al., 2009).

\subsubsection{A focus on snowmelt period in montane streams}

The intensive sampling campaign in spring 2016 at the S-upper montane and

512 the lower montane sites provided no evidence of diurnal pattern for any solutes in the 513 streams (data not shown). However, $\Delta^{17} \mathrm{O}-\mathrm{NO}_{3}{ }^{-}$did follow a diurnal pattern at the S- 
514 upper montane site, a pattern not seen in the lower montane stream (Figure S6a).

515 Conductivity (at both sites) and discharge (lower montane site only) showed very

516 pronounced diurnal variations, highlighting the hydrological influence of snowmelt

517 during the day (Figure S6b and c), also consistent with previous studies in the same

518 location (Mano et al., 2009). At the lower montane site, discharge and conductivity

519 were negatively correlated (Figure $5 d$ ), as their diurnal variations were driven by

520 distinct hydrological regime (i.e., baseflow for conductivity, snowmelt for discharge).

521 That conductivity is controlled by baseflow is also supported by significant positive

522 correlations between weathering solutes and conductivity at the S-upper montane

523 site (Figure 5c). Therefore, assuming a similar relationship between conductivity and

524 discharge is true at the S-upper montane stream, and considering that conductivity

525 and $\Delta^{17} \mathrm{O}-\mathrm{NO}_{3}{ }^{-}$were also negatively correlated (Figure 5a), snowmelt-induced

526 discharge in daytime is certainly the driver of the diurnal variations of $\mathrm{NO}_{3}^{-}$atm exports.

527 Oppositely to another study showing in stream diurnal $\left[\mathrm{NO}_{3}^{-}\right]$variations at snowmelt

528 in northern Vermont (Pellerin et al., 2012), no significant temporal trend in any of the

529 two streams was observed here. Yet, the lower montane stream was only on the

530 rising limb of discharge when sampled, at the very beginning of the snowmelt period.

531 Therefore, the absence of observed diurnal cycle at this site at this time may not be

532 representative of day-night variations later in the season.

\subsection{Isotopic composition of $\mathrm{NO}_{3}^{-}$ter}

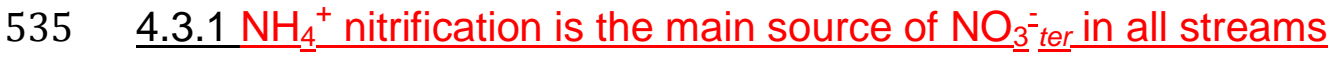

536 Isotopic values of $\mathrm{NO}_{3}{ }^{-}$ter (i.e., $\mathrm{NO}_{3}{ }^{-}$corrected from the atmospheric component

537 accordingly to Eq. 2 and 3$)$ are reported in a dual isotope $\left(\delta^{18} \mathrm{O}\right.$ and $\left.\delta^{15} \mathrm{~N}\right)$ plot in

538 Figure 6. This allows the evaluation of the respective contribution of terrestrial 
539 sources of $\mathrm{NO}_{3}^{-}$ter to streams. Here, most $\delta^{15} \mathrm{~N}^{-} \mathrm{NO}_{3}{ }^{-}$ter in streams span a 0 to $7 \%$

540 range, delineating nitrification of $\mathrm{NH}_{4}{ }^{+}$as the main source of stream $\mathrm{NO}_{3}{ }_{\text {ter }}$ contents

541 (Figure 6). This is in line with watersheds land cover consisting principally in natural

542 or semi-natural vegetation (Table 1 ), where $\mathrm{NO}_{3}{ }^{-}$fertilizers are rarely used. Only very

543 few samples $(\mathrm{n}=4)$ had both $\delta^{15} \mathrm{~N}-\mathrm{NO}_{3}{ }_{\text {ter }}$ and $\delta^{18} \mathrm{O}-\mathrm{NO}_{3}{ }_{\text {ter }}^{-}$characteristic of $\mathrm{NO}_{3}{ }^{-}$

544 fertilizers. It is complicated to segregate the substrate of nitrification (i.e., deposited

545 atmospheric $\mathrm{NH}_{4}{ }^{+}\left(\mathrm{NH}_{4}{ }^{+}\right.$atm $)$or mineralized soil $\mathrm{NH}_{4}{ }^{+}\left(\mathrm{NH}_{4}{ }^{+}\right.$org $\left.)\right)$that led to the

546 production of $\mathrm{NO}_{3}{ }_{\text {ter }}^{-}$in streams. Indeed, nitrification of $\mathrm{NH}_{4}{ }^{+}$atm and $\mathrm{NH}_{4}{ }^{+}$org produces

$547 \mathrm{NO}_{3}{ }^{-}$with overlapping $\delta^{15} \mathrm{~N}$ ranges (Kendall et al., 2007). However, a fraction of

548 samples, mostly from montane streams, had $\delta^{15} \mathrm{~N}-\mathrm{NO}_{3}{ }^{-}$ter lower than $0 \%$, consistent

549 with nitrification of $\mathrm{NH}_{4}{ }^{+}$atm (Kendall et al., 2007; T. Liu et al., 2013).

550

551

4.3.2 Biological removal of $\mathrm{NO}_{3}{ }^{-}$was not predominant in any stream

Weak negative correlations between $\delta^{18} \mathrm{O}-\mathrm{NO}_{3}{ }^{-}$and $\delta^{15} \mathrm{~N}-\mathrm{NO}_{3}{ }^{-}$at all sites,

553 exception made of the lower urban site, indicate that biological processes such as

554 denitrification or assimilation do not control $\mathrm{NO}_{3}{ }^{-}$cycling in streams. Indeed, such

555 processes, if dominant, should enrich residual $\delta^{18} \mathrm{O}-\mathrm{NO}_{3}{ }^{-}$and $\delta^{15} \mathrm{~N}-\mathrm{NO}_{3}{ }^{-}$along a

556 positively correlated line (Granger et al., 2008, 2010; Kendall et al., 2007), in a similar

557 fashion to what is observed at the lower urban site. Yet, that $\delta^{15} \mathrm{~N}-\mathrm{NO}_{3}{ }^{-}$was

558 significantly correlated to $\left[\mathrm{Cl}^{-}\right]$in this stream (data not shown) rather proves that the

559 high $\delta^{15} \mathrm{~N}-\mathrm{NO}_{3}{ }^{-}$values are due to interception of sewage-originated wastewater (Hall

560 et al., 2016). Decreasing $\delta^{15} \mathrm{~N}-\mathrm{NO}_{3}{ }^{-}$and $\left[\mathrm{Cl}^{-}\right]$with discharge (Figure $4 \mathrm{~b}$ and e) at this

561 specific site also supports a groundwater origin of these nitrate pollution episodes. 
$\delta^{18} \mathrm{O}-\mathrm{NO}_{3}{ }^{-}$ter values as low as $-20 \%$ were obtained after removing the

565 atmospheric imprint (Figure 6 and Figure S7). The mean $\delta^{18} \mathrm{O}-\mathrm{NO}_{3}{ }_{\text {ter }}{ }^{\text {ranged }}$

566 between -6.3 and $-8.0 \%$ in the mountainous streams, significantly lower than

567 previously reported values of terrestrial $\delta^{18} \mathrm{O}-\mathrm{NO}_{3}{ }^{-}$in freshwater systems (from -2.9 to

$568-4.2 \%$ in Tsunogai et al. $(2016,2014,2010))$ or produced through in vitro incubation

569 experiments (> 0\% in Burns and Kendall (2002), Mayer et al. (2001) and Spoelstra et

570 al. (2007)). The mean $\delta^{18} \mathrm{O}-\mathrm{NO}_{3}{ }^{-}$ter range between -2.6 and $-2.8 \%$ in the urban

571 streams, far lower than values $>9 \%$ inferred in other urban areas (Riha et al., 2014)

572 or mostly positive values in a semiarid urban setting (Dejwakh et al., 2012).

573 The theoretical range for $\delta^{18} \mathrm{O}-\mathrm{NO}_{3}^{-}$nit (i.e., theoretical $\delta^{18} \mathrm{O}-\mathrm{NO}_{3}{ }^{-}$after

574 nitrification) is -15 to $15 \%$, assuming soil-water and $\mathrm{O}_{2}$ respectively contribute to $\mathrm{NO}_{3}{ }^{-}$

$575-\mathrm{O}$ accordingly to $\delta^{18} \mathrm{O}-\mathrm{NO}_{3}{ }^{-}=1 / 3\left(\delta^{18} \mathrm{O}-\mathrm{O}_{2}\right)+2 / 3\left(\delta^{18} \mathrm{O}-\mathrm{H}_{2} \mathrm{O}\right)$ (Kendall et al., 2007).

576 Here, a subset of 5 snow-water samples and 2 rain samples were analyzed for $\delta^{18} \mathrm{O}$,

577 with respective mean values of -16.6 and $-8.2 \%$. Soil-water isotopes were not directly

578 measured, but assimilated to precipitation water isotopes. Assuming $\delta^{18} \mathrm{O}$ values of

579 air- $\mathrm{O}_{2}$ of $23.88 \%$ (Barkan and $\mathrm{Luz}, 2005$ ), we ended up with $\delta^{18} \mathrm{O}-\mathrm{NO}_{3}{ }^{-}=-3.3 \%$ (if

580 the end-member is snow water) and $+2.3 \%$ (if the end-member is rain water) for $\mathrm{NO}_{3}{ }^{-}$

581 nit. Even though this approach comes with a number of assumptions and caveats

582 (Rose et al., 2015b; Snider et al., 2010), the calculated values are significantly higher

583 - by ca $4 \%$ - than the mean annual $\delta^{18} \mathrm{O}-\mathrm{NO}_{3}{ }^{-}$ter (Table 3 ). In a study focusing on an

584 estuarine system in San Francisco Bay, it was postulated that rapid recycling of $\mathrm{NO}_{3}{ }^{-}$

585 under low $\left[\mathrm{NO}_{3}{ }^{-}\right]$conditions $\left(<0.9 \mathrm{mg} \mathrm{L}^{-1}\right)$ could result in an increased incorporation of

$586 \mathrm{H}_{2} \mathrm{O}-\mathrm{O}$ atoms into the $\mathrm{NO}_{3}{ }^{-}$molecule (Wankel et al., 2006). Another work focusing on

587 nitrification in forests soils of central Japan attributed low $\delta^{18} \mathrm{O}-\mathrm{NO}_{3}{ }^{-}$to a combination

588 of $\mathrm{O}$ atoms exchange between $\mathrm{H}_{2} \mathrm{O}$ and $\mathrm{NO}_{2}^{-}$and kinetic isotope fractionation 
associated with oxygen incorporation throughout the nitrification process in acidic soils (Fang et al., 2012). The latter hypothesis could explain the generally acidic subalpine soils characterized by slow $\mathrm{N}$ cycling (Robson et al., 2007), but further investigation is warranted to understand the cause of ${ }^{18} \mathrm{O}$ depleted $\mathrm{NO}_{3}$. When calculating $f_{\text {atm }}$ using the approach described by Barnes et al. (2008):

(Eq.7)

$$
f_{\text {atm }}=\left(\delta^{18} O_{\text {sample }}-\delta^{18} O_{n i t}\right) /\left(\delta^{18} O_{a t m}-\delta^{18} O_{n i t}\right)
$$

and by using either $\delta^{18} \mathrm{O}-\mathrm{NO}_{3}{ }_{\text {ter }}$ or $\delta^{18} \mathrm{O}-\mathrm{NO}_{3}^{-}$nit as nitrification end-member, significant differences between the estimated $f_{\text {atm }}$ are obtained (Table 3). These findings suggest that atmospheric $\mathrm{NO}_{3}{ }^{-}$inputs to an ecosystem are underestimated (e.g., up to $6 \%$ in this study, Table 3) when calculated using Eq.7 with $\delta^{18} \mathrm{O}^{-\mathrm{NO}_{3}}{ }^{-}$nit as nitrification end-member.

\section{Conclusions}

The results showing higher $\mathrm{NO}_{3}{ }^{-}$atm exports in a montane stream relative to urban streams have several key implications. First, it sheds light on the contribution of snowmelt-derived groundwater to year-round $\mathrm{NO}_{3}{ }^{-}$atm exports in all streams at baseflow. Contamination of groundwater by $\mathrm{NO}_{3}{ }^{-}$atm may be a widespread phenomenon, regardless of emitting sources proximity: other studies also reported ubiquitous presence of $\mathrm{NO}_{3}{ }^{-}$atm in groundwater (Dejwakh et al., 2012; Dietzel et al., 2014; Nakagawa et al., 2013; Stoewer et al., 2015). Second, hydrological events (e.g., snowmelt) are the main controls of upland $\mathrm{NO}_{3}{ }^{-}$atm exports, whereas a chemically equilibrated groundwater reservoir dominates discharge in urban streams. In a context of climate change, with temporally shorter and shallower snow coverage 
614 of altitude catchments, decreasing exports of $\mathrm{NO}_{3}{ }^{-}$atm by snowmelt water could result

615 in proportional $\mathrm{NO}_{3}{ }^{-}$atm enrichment of alpine soils. However, how this would correlate

616 with elsewhere reported snow cover removal effects on microbial communities, $\mathrm{N}$

617 retention, plants biomass and soil respiration is a complex question yet to be

618 addressed (Brooks et al., 2011; Gavazov et al., 2017; Sorensen et al., 2016;

619 Vankoughnett and Henry, 2013). Third, the association of $\Delta^{17} \mathrm{O}, \delta^{15} \mathrm{~N}$ and $\delta^{18} \mathrm{O}$ is a

620 potent tool to unravel the respective atmospheric and terrestrial sources contribution

621 to $\mathrm{NO}_{3}{ }^{-}$pools. To correct the $\delta^{18} \mathrm{O}-\mathrm{NO}_{3}{ }^{-}$from its atmospheric composition enables the

622 determination of the $\delta^{18} \mathrm{O}-\mathrm{NO}_{3}{ }^{-}$ter, which came significantly lower at all sites than the

623 theoretically calculated $\delta^{18} \mathrm{O}-\mathrm{NO}_{3}{ }^{-}$nit. This resulted in significantly higher estimated

$624 f_{\text {atm }}$ when using a more robust $\delta^{18} \mathrm{O}-\mathrm{NO}_{3}{ }_{\text {ter }}^{-}$(compared to $\delta^{18} \mathrm{O}-\mathrm{NO}_{3}{ }^{-}$nit) as nitrification

625 end-member in Eq.7. Studies that did not use $\delta^{18} \mathrm{O}-\mathrm{NO}_{3}{ }_{\text {ter }}^{-}$in Eq.7 to determine $f_{\text {atm }}$

626 may have underestimated atmospheric nitrate inputs to the environment (e.g.,

627 Barnes et al. (2008), Durka et al. (1994), Griffiths et al. (2016), Pellerin et al. (2012),

628 Sebestyen et al. (2014)). It is recommended that more work be conducted using the

629 triple isotope technique to revise the assessment of $\mathrm{NO}_{3}{ }^{-}$atm ubiquity in the

630 environment.

631

632 Ackowledgments

633 This study was supported by grants from the Labex OSUG@2020 (“Investissements

634 d'avenir" - ANR10 LABX56), the ARC - Environnement Région Rhone-Alpes, the

635 Grenoble-Chambéry DIPEE CNRS. This work also benefited from the National

636 Research Agency supports ("Investissements d'avenir” - ANR11 INBS-0001AnaEE -

637 Services and "FloodScale project" - ANR 2011 BS56 027) and from the SAJF

638 research station (UMR 3370, UGA-CNRS) infrastructures and competences. The 
study took place on a Long Term Ecological Research site of the ZAA (Zone Atelier

Alpes) and the Isère Campus monitoring site is a CNRS-labeled site of the ZABR

(Rhone Basin Long Term Ecological Research site). We would like to thank G. Nord,

J.-L. Jaffrezo, F. Masson, V. Lucaire, E. Vince and C. Arnoldi for help with either

laboratory or field work. We also want to acknowledge J. Renaud for help with SIG.

\section{Appendix A}

The supplementary information provides additional Text on the analytical methods,

Figures S1-S7 and Tables S1-S2.

\section{References}

650 Aber, J.D., Nadelhoffer, K.J., Steudler, P., Melillo, J.M., 1989. Nitrogen Saturation in

651 Northern Forest Ecosystems. BioScience 39, 378-386.

652 https://doi.org/10.2307/1311067

653 Balestrini, R., Arese, C., Freppaz, M., Buffagni, A., 2013. Catchment features controlling nitrogen dynamics in running waters above the tree line (central Italian Alps). Hydrol. Earth Syst. Sci. 17, 989-1001. https://doi.org/10.5194/hess-17-989-2013 Barkan, E., Luz, B., 2005. High precision measurements of 170/160 and 180/160 ratios in H20. Rapid Commun. Mass Spectrom. 19, 3737-3742.

658 https://doi.org/10.1002/rcm.2250

659 Barnes, R.T., Raymond, P.A., 2010. Land-use controls on sources and processing of 660 nitrate in small watersheds: insights from dual isotopic analysis. Ecol. Appl. 20, 1961661 1978. https://doi.org/10.1890/08-1328.1

662 Barnes, R.T., Raymond, P.A., Casciotti, K.L., 2008. Dual isotope analyses indicate efficient 663 processing of atmospheric nitrate by forested watersheds in the northeastern US.

664 Biogeochemistry 90, 15-27.

665 Barnes, R.T., Williams, M.W., Parman, J.N., Hill, K., Caine, N., 2014. Thawing glacial and 666 permafrost features contribute to nitrogen export from Green Lakes Valley, Colorado 667 Front Range, USA. Biogeochemistry 117, 413-430. https://doi.org/10.1007/s10533668 013-9886-5

669 Baron, J.S., Campbell, D.H., 1997. Nitrogen fluxes in a high elevation Colorado Rocky 670 Mountain basin. Hydrol. Process. 11, 783-799.

671 Baron, J.S., Driscoll, C.T., Stoddard, J.L., Richer, E.E., 2011. Empirical Critical Loads of 672 Atmospheric Nitrogen Deposition for Nutrient Enrichment and Acidification of Sensitive 673 US Lakes. BioScience 61, 602-613. https://doi.org/10.1525/bio.2011.61.8.6 674 Baron, J.S., Nydick, K.R., Rueth, H.M., Lafrançois, B.M., Wolfe, A.P., 2005. High Elevation 675 Ecosystem Responses to Atmospheric Deposition of Nitrogen in the Colorado Rocky 676 Mountains, USA, in: Huber, U.M., Bugmann, H.K.M., Reasoner, M.A. (Eds.), Global Change and Mountain Regions. Springer Netherlands, Dordrecht, pp. 429-436. 
Baron, J.S., Rueth, H.M., Wolfe, A.M., Nydick, K.R., Allstott, E.J., Minear, J.T., Moraska, B., 2000. Ecosystem Responses to Nitrogen Deposition in the Colorado Front Range. Ecosystems 3, 352-368. https://doi.org/10.1007/s100210000032 Beirle, S., Boersma, K.F., Platt, U., Lawrence, M.G., Wagner, T., 2011. Megacity Emissions https://doi.org/10.1126/science.1207824

Bettez, N.D., Groffman, P.M., 2013. Nitrogen Deposition in and near an Urban Ecosystem. Environ. Sci. Technol. 47, 6047-6051. https://doi.org/10.1021/es400664b Beyn, F., Matthias, V., Dähnke, K., 2014. Changes in atmospheric nitrate deposition in Germany - An isotopic perspective. Environ. Pollut. 194, 1-10. https://doi.org/10.1016/j.envpol.2014.06.043 Bodin, X., Thibert, E., Fabre, D., Ribolini, A., Schoeneich, P., Francou, B., Reynaud, L., Fort, M., 2009. Two decades of responses (1986-2006) to climate by the Laurichard rock glacier, French Alps. Permafr. Periglac. Process. 20, 331-344. https://doi.org/10.1002/ppp.665

Bourgeois, I., 2017. Atmospheric nitrate deposition on subalpine meadows of the Lautaret pass (phdthesis). Université Grenoble Alpes. Bourgeois, I., Savarino, J., Caillon, N., Angot, H., Barbero, A., Delbart, F., Voisin, D., Clement, J.-C., n.d. Tracing the fate of atmospheric nitrate in a subalpine watershed using $\Delta 170$. Environ. Sci. Technol. in review.

Bowman, W.D., Gartner, J.R., Holland, K., Wiedermann, M., 2006. Nitrogen Critical Loads For Alpine Vegetation And Terrestrial Ecosystem Response: Are We There Yet? Ecol. Appl. 16, 1183-1193. https://doi.org/10.1890/10510761(2006)016[1183:NCLFAV]2.0.CO;2

Briand, C., 2014. Approche multi-traceurs pour la détermination de l'origine des nitrates dans les eaux souterraines: exemple d'une source karstique dans les Landes. Université Pierre et Marie Curie-Paris VI.

Brooks, P.D., Campbell, D.H., Tonnessen, K.A., Heuer, K., 1999. Natural variability in N export from headwater catchments: snow cover controls on ecosystem $\mathrm{N}$ retention. Hydrol. Process. 13, 2191-2201.

Brooks, P.D., Grogan, P., Templer, P.H., Groffman, P., Öquist, M.G., Schimel, J., 2011. Carbon and Nitrogen Cycling in Snow-Covered Environments. Geogr. Compass 5, 682699. https://doi.org/10.1111/j.1749-8198.2011.00420.x

Burns, D.A., Boyer, E.W., Elliott, E.M., Kendall, C., 2009. Sources and Transformations of Nitrate from Streams Draining Varying Land Uses: Evidence from Dual Isotope Analysis. J. Environ. Qual. 38, 1149. https://doi.org/10.2134/jeq2008.0371

Burns, D.A., Kendall, C., 2002. Analysis of $\delta 15 \mathrm{~N}$ and $\delta 180$ to differentiate NO3- sources in runoff at two watersheds in the Catskill Mountains of New York. Water Resour. Res. 38, 9-1. https://doi.org/10.1029/2001WR000292

Campbell, D.H., Clow, D.W., Ingersoll, G.P., Mast, M.A., Spahr, N.E., Turk, J.T., 1995. Nitrogen deposition and release in alpine watersheds, Loch Vale, Colorado, USA. IAHS Publ.-Ser. Proc. Rep.-Intern Assoc Hydrol. Sci. 228, 243-254.

Campbell, D.H., Kendall, C., Chang, C.C.Y., Silva, S.R., Tonnessen, K.A., 2002. Pathways for nitrate release from an alpine watershed: Determination using $\delta{ }^{15} \mathrm{~N}$ and $\delta{ }^{18} \mathrm{O}$ : ALPINE WATERSHED NITRATE $\delta^{15}$ N AND $\delta{ }^{18}$ 0. Water Resour. Res. 38, 10-1-10-9. https://doi.org/10.1029/2001WR000294 Clark, C.M., Bell, M.D., Boyd, J.W., Compton, J.E., Davidson, E.A., Davis, C., Fenn, M.E., Geiser, L., Jones, L., Blett, T.F., 2017. Nitrogen-induced terrestrial eutrophication: cascading effects and impacts on ecosystem services. Ecosphere 8, e01877. 
728 Clément, J.-C., Holmes, R.M., Peterson, B.J., Pinay, G., 2003. Isotopic investigation of denitrification in a riparian ecosystem in western France. J. Appl. Ecol. 40, 1035-1048. https://doi.org/10.1111/j.1365-2664.2003.00854.x Clow, D.W., Sueker, J.K., 2000. Relations between basin characteristics and stream water chemistry in alpine/subalpine basins in Rocky Mountain National Park, Colorado. Water Resour. Res. 36, 49-61. https://doi.org/10.1029/1999WR900294 Costa, A.W., Michalski, G., Schauer, A.J., Alexander, B., Steig, E.J., Shepson, P.B., 2011. Analysis of atmospheric inputs of nitrate to a temperate forest ecosystem from $\Delta{ }^{17} \mathrm{O}$ isotope ratio measurements: ATMOSPHERIC NITRATE INPUTS TO A FOREST. Geophys. Res. Lett. 38, n/a-n/a. https://doi.org/10.1029/2011GL047539 Cowie, R.M., Knowles, J.F., Dailey, K.R., Williams, M.W., Mills, T.J., Molotch, N.P., 2017. 163-178. https://doi.org/10.1016/j.jhydrol.2017.03.044

Decina, S.M., Templer, P.H., Hutyra, L.R., Gately, C.K., Rao, P., 2017. Variability, drivers, and effects of atmospheric nitrogen inputs across an urban area: Emerging patterns among human activities, the atmosphere, and soils. Sci. Total Environ. 609, 1524-1534. https://doi.org/10.1016/j.scitotenv.2017.07.166

Dejwakh, N.R., Meixner, T., Michalski, G., McIntosh, J., 2012. Using 170 to Investigate Nitrate Sources and Sinks in a Semi-Arid Groundwater System. Environ. Sci. Technol. 46, 745-751. https://doi.org/10.1021/es203450z

Devito, K.J., Fitzgerald, D., Hill, A.R., Aravena, R., 2000. Nitrate dynamics in relation to lithology and hydrologic flow path in a river riparian zone. J. Environ. Qual. 29, 10751084.

Dietzel, M., Leis, A., Abdalla, R., Savarino, J., Morin, S., Böttcher, M.E., Köhler, S., 2014. \&lt;sup\&gt;17\&lt;/sup\&gt;0 excess traces atmospheric nitrate in paleo-groundwater of the Saharan desert. Biogeosciences 11, 3149-3161. https://doi.org/10.5194/bg-113149-2014

Dodds, W.K., Bouska, W.W., Eitzmann, J.L., Pilger, T.J., Pitts, K.L., Riley, A.J., Schloesser, J.T., Thornbrugh, D.J., 2009. Eutrophication of U.S. Freshwaters: Analysis of Potential Economic Damages. Environ. Sci. Technol. 43, 12-19. https://doi.org/10.1021/es801217q Durka, W., Schulze, E.-D., Gebauer, G., Voerkeliust, S., 1994. Effects of forest decline on uptake and leaching of deposited nitrate determined from $15 \mathrm{~N}$ and 180 measurements. Nature 372, 765-767. https://doi.org/10.1038/372765a0

Dutordoir, S., 2014. Bilan des flux de métaux, carbone organique et nutriments contenus dans une rivière alpine: part des rejets urbains de l'agglomération de Grenoble et apports amont (Isère et Drac). Université Grenoble Alpes.

Elliott, E.M., Kendall, C., Boyer, E.W., Burns, D.A., Lear, G.G., Golden, H.E., Harlin, K., Bytnerowicz, A., Butler, T.J., Glatz, R., 2009. Dual nitrate isotopes in dry deposition: Utility for partitioning $\mathrm{NO}_{\mathrm{x}}$ source contributions to landscape nitrogen deposition. J. Geophys. Res. 114. https://doi.org/10.1029/2008JG000889

Elser, J.J., Andersen, T., Baron, J.S., Bergström, A.-K., Jansson, M., Kyle, M., Nydick, K.R., Steger, L., Hessen, D.0., 2009. Shifts in lake N:P stoichiometry and nutrient limitation driven by atmospheric nitrogen deposition. Science 326, 835-837. https://doi.org/10.1126/science.1176199 Emmerton, K.S., Callaghan, T.V., Jones, H.E., Leake, J.R., Michelsen, A., Read, D.J., 2001. Assimilation and Isotopic Fractionation of Nitrogen by Mycorrhizal and Nonmycorrhizal Subarctic Plants. New Phytol. 151, 513-524. https://doi.org/10.2307/1353802 
Erbland, J., 2011. Contraintes isotopiques sur l'interprétation de l'enregistrement en nitrate dans la carotte de glace de Vostok. Université de Grenoble.

Estrada, N.L., Böhlke, J.K., Sturchio, N.C., Gu, B., Harvey, G., Burkey, K.O., Grantz, D.A., McGrath, M.T., Anderson, T.A., Rao, B., Sevanthi, R., Hatzinger, P.B., Jackson, W.A., 2017. Stable isotopic composition of perchlorate and nitrate accumulated in plants: Hydroponic experiments and field data. Sci. Total Environ. 595, 556-566. https://doi.org/10.1016/j.scitotenv.2017.03.223

Fang, Y., Koba, K., Makabe, A., Takahashi, C., Zhu, W., Hayashi, T., Hokari, A.A., Urakawa, R., Bai, E., Houlton, B.Z., Xi, D., Zhang, S., Matsushita, K., Tu, Y., Liu, D., Zhu, F., Wang, Z., Zhou, G., Chen, D., Makita, T., Toda, H., Liu, X., Chen, Q., Zhang, D., Li, Y., Yoh, M., 2015. Microbial denitrification dominates nitrate losses from forest ecosystems. Proc. Natl. Acad. Sci. 112, 1470-1474. https://doi.org/10.1073/pnas.1416776112

Fang, Y., Koba, K., Makabe, A., Zhu, F., Fan, S., Liu, X., Yoh, M., 2012. Low $\delta 180$ Values of Nitrate Produced from Nitrification in Temperate Forest Soils. Environ. Sci. Technol. 46, 8723-8730. https://doi.org/10.1021/es300510r

Fang, Y., Yoh, M., Koba, K., Zhu, W., Takebayashi, Y., Xiao, Y., Lei, C., Mo, J., Zhang, W., Lu, X., 2011. Nitrogen deposition and forest nitrogen cycling along an urban-rural transect in southern China: FOREST N CYCLING IN SOUTHERN CHINA. Glob. Change Biol. 17, 872-885. https://doi.org/10.1111/j.1365-2486.2010.02283.x

Fowler, D., Steadman, C.E., Stevenson, D., Coyle, M., Rees, R.M., Skiba, U.M., Sutton, M.A., Cape, J.N., Dore, A.J., Vieno, M., Simpson, D., Zaehle, S., Stocker, B.D., Rinaldi, M., Facchini, M.C., Flechard, C.R., Nemitz, E., Twigg, M., Erisman, J.W., Butterbach-Bahl, K., Galloway, J.N., 2015. Effects of global change during the 21st century onthe nitrogen cycle. Atmospheric Chem. Phys. 15, 13849-13893. https://doi.org/10.5194/acp-15-138492015

Frey, M.M., Savarino, J., Morin, S., Erbland, J., Martins, J.M.F., 2009. Photolysis imprint in the nitrate stable isotope signal in snow and atmosphere of East Antarctica and implications for reactive nitrogen cycling. Atmospheric Chem. Phys. 9, 8681-8696. Freyer, H.D., 1991. Seasonal variation of $15 \mathrm{~N} / 14 \mathrm{~N}$ ratios in atmospheric nitrate species. Tellus B 43, 30-44. https://doi.org/10.1034/j.1600-0889.1991.00003.x Galloway, J.N., Dentener, F.J., Capone, D.G., Boyer, E.W., Howarth, R.W., Seitzinger, S.P., Asner, G.P., Cleveland, C.C., Green, P.A., Holland, E.A., Karl, D.M., Michaels, A.F., Porter, J.H., Townsend, A.R., V ?osmarty, C.J., 2004. Nitrogen Cycles: Past, Present, and Future. Biogeochemistry 70, 153-226. https://doi.org/10.1007/s10533-004-0370-0 Galloway, J.N., Townsend, A.R., Erisman, J.W., Bekunda, M., Cai, Z., Freney, J.R., Martinelli, L.A., Seitzinger, S.P., Sutton, M.A., 2008. Transformation of the nitrogen cycle: recent trends, questions, and potential solutions. Science 320, 889-892.

Gavazov, K., Ingrisch, J., Hasibeder, R., Mills, R.T.E., Buttler, A., Gleixner, G., Pumpanen, J., Bahn, M., 2017. Winter ecology of a subalpine grassland: Effects of snow removal on soil respiration, microbial structure and function. Sci. Total Environ. 590-591, 316-324. https://doi.org/10.1016/j.scitotenv.2017.03.010

Granger, J., Sigman, D.M., Lehmann, M.F., Tortell, P.D., 2008. Nitrogen and oxygen isotope fractionation during dissimilatory nitrate reduction by denitrifying bacteria. Limnol. Oceanogr. 53, 2533.

Granger, J., Sigman, D.M., Needoba, J.A., Harrison, P.J., 2004. Coupled nitrogen and oxygen isotope fractionation of nitrate during assimilation by cultures of marine phytoplankton. Limnol. Oceanogr. 49, 1763-1773.

Granger, J., Sigman, D.M., Rohde, M.M., Maldonado, M.T., Tortell, P.D., 2010. N and 0 isotope effects during nitrate assimilation by unicellular prokaryotic and eukaryotic 
plankton cultures. Geochim. Cosmochim. Acta 74, 1030-1040.

826 https://doi.org/10.1016/j.gca.2009.10.044

827 Granger, J., Wankel, S.D., 2016. Isotopic overprinting of nitrification on denitrification as a ubiquitous and unifying feature of environmental nitrogen cycling. Proc. Natl. Acad. nitrate isotopes clarify the role of biological processing and hydrologic flow paths on nitrogen cycling in subtropical low-gradient watersheds: N CYCLING IN LOW-RELIEF WATERSHEDS. J. Geophys. Res. Biogeosciences 121, 422-437. https://doi.org/10.1002/2015JG003189 Groffman, P.M., Law, N.L., Belt, K.T., Band, L.E., Fisher, G.T., 2004. Nitrogen Fluxes and Retention in Urban Watershed Ecosystems. Ecosystems 7. https://doi.org/10.1007/s10021-003-0039-x

Hall, S.J., Maurer, G., Hoch, S.W., Taylor, R., Bowling, D.R., 2014. Impacts of anthropogenic emissions and cold air pools on urban to montane gradients of snowpack ion concentrations in the Wasatch Mountains, Utah. Atmos. Environ. 98, 231-241. https://doi.org/10.1016/j.atmosenv.2014.08.076 Hall, S.J., Weintraub, S.R., Eiriksson, D., Brooks, P.D., Baker, M.A., Bowen, G.J., Bowling, D.R., 2016. Stream Nitrogen Inputs Reflect Groundwater Across a Snowmelt-Dominated Montane to Urban Watershed. Environ. Sci. Technol. 50, 1137-1146. https://doi.org/10.1021/acs.est.5b04805 Hastings, M.G., Jarvis, J.C., Steig, E.J., 2009. Anthropogenic Impacts on Nitrogen Isotopes of Ice-Core Nitrate. Science 324, 1288-1288. https://doi.org/10.1126/science.1170510 Hertel, O., Skjøth, C.A., Reis, S., Bleeker, A., Harrison, R.M., Cape, J.N., Fowler, D., Skiba, U., Simpson, D., Jickells, T., Kulmala, M., Gyldenkærne, S., Sørensen, L.L., Erisman, J.W., Sutton, M.A., 2012. Governing processes for reactive nitrogen compounds in the European atmosphere. Biogeosciences 9, 4921-4954. https://doi.org/10.5194/bg-94921-2012

Holtgrieve, G.W., Schindler, D.E., Hobbs, W.O., Leavitt, P.R., Ward, E.J., Bunting, L., Chen, G., Finney, B.P., Gregory-Eaves, I., Holmgren, S., Lisac, M.J., Lisi, P.J., Nydick, K., Rogers, L.A., Saros, J.E., Selbie, D.T., Shapley, M.D., Walsh, P.B., Wolfe, A.P., 2011. A Coherent Signature of Anthropogenic Nitrogen Deposition to Remote Watersheds of the Northern Hemisphere. Science 334, 1545-1548. https://doi.org/10.1126/science.1212267 Hood, E., Scott, D., 2008. Riverine organic matter and nutrients in southeast Alaska affected by glacial coverage. Nat. Geosci. 1, 583-587. https://doi.org/10.1038/ngeo280 Hundey, E.J., Russell, S.D., Longstaffe, F.J., Moser, K.A., 2016. Agriculture causes nitrate fertilization of remote alpine lakes. Nat. Commun. 7, 10571.

https://doi.org/10.1038/ncomms10571

Kaiser, J., Hastings, M.G., Houlton, B.Z., Röckmann, T., Sigman, D.M., 2007. Triple Oxygen Isotope Analysis of Nitrate Using the Denitrifier Method and Thermal Decomposition of $\mathrm{N}_{2}$ O. Anal. Chem. 79, 599-607. https://doi.org/10.1021/ac061022s Kaye, J.P., Hart, S.C., 1997. Competition for nitrogen between plants and soil microorganisms. Trends Ecol. Evol. 12, 139-143. https://doi.org/10.1016/S01695347(97)01001-X

Kean, A.J., Harley, R.A., Littlejohn, D., Kendall, G.R., 2000. On-Road Measurement of Ammonia and Other Motor Vehicle Exhaust Emissions. Environ. Sci. Technol. 34, 35353539. https://doi.org/10.1021/es991451q

Kendall, C., Campbell, D.H., Burns, D.A., Shanley, J.B., Silva, S.R., Chang, C.C., 1995. Tracing sources of nitrate in snowmelt runoff using the oxygen and nitrogen isotopic 
compositions of nitrate. IAHS Publ.-Ser. Proc. Rep.-Intern Assoc Hydrol. Sci. 228, 339348.

Kendall, C., Elliott, E.M., Wankel, S.D., 2007. Tracing anthropogenic inputs of nitrogen to ecosystems. Stable Isot. Ecol. Environ. Sci. 2, 375-449.

Kirchner, M., Fegg, W., Römmelt, H., Leuchner, M., Ries, L., Zimmermann, R., Michalke, B., Wallasch, M., Maguhn, J., Faus-Kessler, T., Jakobi, G., 2014. Nitrogen deposition along differently exposed slopes in the Bavarian Alps. Sci. Total Environ. 470-471, 895-906. https://doi.org/10.1016/j.scitotenv.2013.10.036

Lefebvre, S., Clément, J.-C., Pinay, G., Thenail, C., Durand, P., Marmonier, P., 2007. 15nNitrate Signature in Low-Order Streams: Effects of Land Cover and Agricultural Practices. Ecol. Appl. 17, 2333-2346. https://doi.org/10.1890/06-1496.1 Liu, T., Wang, F., Michalski, G., Xia, X., Liu, S., 2013. Using ${ }^{15}$ N, ${ }^{17}$ O, and 18 O To Determine Nitrate Sources in the Yellow River, China. Environ. Sci. Technol. 47, 13412-13421. https://doi.org/10.1021/es403357m

Liu, X.-Y., Koba, K., Takebayashi, Y., Liu, C.-Q., Fang, Y.-T., Yoh, M., 2013. Dual N and O isotopes of nitrate in natural plants: first insights into individual variability and organspecific patterns. Biogeochemistry 114, 399-411. https://doi.org/10.1007/s10533-0129721-4

Louiseize, N.L., Lafrenière, M.J., Hastings, M.G., 2014. Stable isotopic evidence of enhanced export of microbially derived $\$ \$\{\backslash \text { text }\{\mathrm{NO}\}\}_{-}\{3\}^{\wedge}\{-\} \$ \$ \mathrm{NO} 3$ - following active layer slope disturbance in the Canadian High Arctic. Biogeochemistry 121, 565-580. https://doi.org/10.1007/s10533-014-0023-x

Lovett, G.M., Goodale, C.L., 2011. A New Conceptual Model of Nitrogen Saturation Based on Experimental Nitrogen Addition to an Oak Forest. Ecosystems 14, 615-631. https://doi.org/10.1007/s10021-011-9432-z

Mano, V., 2008. Processus fondamentaux conditionnant les apports de sediments fins dans les retenues-Optimisation des methodes de mesure et modelisation statistique. Université Joseph-Fourier-Grenoble I.

Mano, V., Nemery, J., Belleudy, P., Poirel, A., 2009. Assessment of suspended sediment transport in four alpine watersheds (France): influence of the climatic regime. Hydrol. Process. 23, 777-792. https://doi.org/10.1002/hyp.7178 Mara, P., Mihalopoulos, N., Gogou, A., Daehnke, K., Schlarbaum, T., Emeis, K.-C., Krom, M., 2009. Isotopic composition of nitrate in wet and dry atmospheric deposition on Crete in the eastern Mediterranean Sea: ISOTOPIC COMPOSITION OF NITRATE IN DEPOSITION. Glob. Biogeochem. Cycles 23, n/a-n/a. https://doi.org/10.1029/2008GB003395 Mast, M.A., Clow, D.W., Baron, J.S., Wetherbee, G.A., 2014. Links between N Deposition and Nitrate Export from a High-Elevation Watershed in the Colorado Front Range. Environ. Sci. Technol. 48, 14258-14265. https://doi.org/10.1021/es502461k Matson, P., Lohse, K.A., Hall, S.J., 2002. The Globalization of Nitrogen Deposition: Consequences for Terrestrial Ecosystems. AMBIO J. Hum. Environ. 31, 113. https://doi.org/10.1639/0044-7447(2002)031[0113:TGONDC]2.0.CO;2 Mayer, B., Bollwerk, S.M., Mansfeldt, T., Hütter, B., Veizer, J., 2001. The oxygen isotope composition of nitrate generated by nitrification in acid forest floors. Geochim. Cosmochim. Acta 65, 2743-2756. https://doi.org/10.1016/S0016-7037(01)00612-3 Mayer, B., Boyer, E.W., Goodale, C., Jaworski, N.A., Van Breemen, N., Howarth, R.W., Seitzinger, S., Billen, G., Lajtha, K., Nadelhoffer, K., others, 2002. Sources of nitrate in rivers draining sixteen watersheds in the northeastern US: Isotopic constraints. Biogeochemistry 57, 171-197.

Michalski, G., Kolanowski, M., Riha, K.M., 2015. Oxygen and nitrogen isotopic 
composition of nitrate in commercial fertilizers, nitric acid, and reagent salts. Isotopes Environ. Health Stud. 51, 382-391. https://doi.org/10.1080/10256016.2015.1054821 Michalski, G., Meixner, T., Fenn, M., Hernandez, L., Sirulnik, A., Allen, E., Thiemens, M., 2004. Tracing Atmospheric Nitrate Deposition in a Complex Semiarid Ecosystem Using $\Delta$ 170. Environ. Sci. Technol. 38, 2175-2181. https://doi.org/10.1021/es034980+ 2009. Comprehensive isotopic composition of atmospheric nitrate in the Atlantic Ocean boundary layer from $65^{\circ} \mathrm{S}$ to $79^{\circ} \mathrm{N}$. J. Geophys. Res. 114 .

932

933

934 https://doi.org/10.1029/2008JD010696 Morin, S., Savarino, J., Frey, M.M., Yan, N., Bekki, S., Bottenheim, J.W., Martins, J.M.F., 2008. Tracing the Origin and Fate of NOx in the Arctic Atmosphere Using Stable Isotopes in Nitrate. Science 322, 730-732. https://doi.org/10.1126/science.1161910

Nakagawa, F., Suzuki, A., Daita, S., Ohyama, T., Komatsu, D.D., Tsunogai, U., 2013. Tracing atmospheric nitrate in groundwater using triple oxygen isotopes: evaluation based on bottled drinking water. Biogeosciences 10, 3547-3558.

Nanus, L., McMurray, J.A., Clow, D.W., Saros, J.E., Blett, T., Gurdak, J.J., 2017. Spatial variation of atmospheric nitrogen deposition and critical loads for aquatic ecosystems in the Greater Yellowstone Area. Environ. Pollut. 223, 644-656.

https://doi.org/10.1016/j.envpol.2017.01.077

Nanus, L., Williams, M.W., Campbell, D.H., Elliott, E.M., Kendall, C., 2008. Evaluating Regional Patterns in Nitrate Sources to Watersheds in National Parks of the Rocky Mountains using Nitrate Isotopes. Environ. Sci. Technol. 42, 6487-6493. https://doi.org/10.1021/es800739e

Némery, J., Mano, V., Coynel, A., Etcheber, H., Moatar, F., Meybeck, M., Belleudy, P., Poirel, A., 2013. Carbon and suspended sediment transport in an impounded alpine river (Isère, France). Hydrol. Process. 27, n/a-n/a. https://doi.org/10.1002/hyp.9387

Ohte, N., Sebestyen, S.D., Shanley, J.B., Doctor, D.H., Kendall, C., Wankel, S.D., Boyer, E.W., 2004. Tracing sources of nitrate in snowmelt runoff using a high-resolution isotopic technique: TRACING SOURCES OF NITRATE IN SNOWMELT RUNOFF. Geophys. Res. Lett. 31, n/a-n/a. https://doi.org/10.1029/2004GL020908

Pellerin, B.A., Saraceno, J.F., Shanley, J.B., Sebestyen, S.D., Aiken, G.R., Wollheim, W.M., Bergamaschi, B.A., 2012. Taking the pulse of snowmelt: in situ sensors reveal seasonal, event and diurnal patterns of nitrate and dissolved organic matter variability in an upland forest stream. Biogeochemistry 108, 183-198. https://doi.org/10.1007/s10533011-9589-8

Preunkert, S., 2003. A seasonally resolved alpine ice core record of nitrate: Comparison with anthropogenic inventories and estimation of preindustrial emissions of $\mathrm{NO}$ in Europe. J. Geophys. Res. 108. https://doi.org/10.1029/2003JD003475 Rao, P., Hutyra, L.R., Raciti, S.M., Templer, P.H., 2014. Atmospheric nitrogen inputs and losses along an urbanization gradient from Boston to Harvard Forest, MA. Biogeochemistry 121, 229-245. https://doi.org/10.1007/s10533-013-9861-1 Riha, K.M., Michalski, G., Gallo, E.L., Lohse, K.A., Brooks, P.D., Meixner, T., 2014. High Atmospheric Nitrate Inputs and Nitrogen Turnover in Semi-arid Urban Catchments. Ecosystems 17, 1309-1325. https://doi.org/10.1007/s10021-014-9797-x Robson, T., Lavorel, S., Clement, J., Roux, X., 2007. Neglect of mowing and manuring leads to slower nitrogen cycling in subalpine grasslands. Soil Biol. Biochem. 39, 930-941. https://doi.org/10.1016/j.soilbio.2006.11.004 Rogora, M., Mosello, R., Arisci, S., Brizzio, M.C., Barbieri, A., Balestrini, R., Waldner, P., Schmitt, M., Stähli, M., Thimonier, A., Kalina, M., Puxbaum, H., Nickus, U., Ulrich, E., 
Probst, A., 2006. An Overview of Atmospheric Deposition Chemistry over the Alps: Present Status and Long-term Trends. Hydrobiologia 562, 17-40. https://doi.org/10.1007/s10750-005-1803-z Rose, L.A., Elliott, E.M., Adams, M.B., 2015a. Triple Nitrate Isotopes Indicate Differing Nitrate Source Contributions to Streams Across a Nitrogen Saturation Gradient. Ecosystems 18, 1209-1223. https://doi.org/10.1007/s10021-015-9891-8 Rose, L.A., Sebestyen, S.D., Elliott, E.M., Koba, K., 2015b. Drivers of atmospheric nitrate processing and export in forested catchments. Water Resour. Res. 51, 1333-1352.

980 https://doi.org/10.1002/2014WR015716

981

982

983

984

985

986

987

988

989

990

991

992

993

994

995

996

997

998

999

1000

1001

1002

1003

1004

1005

1006

1007

1008

1009

1010

1011

1012

1013

1014

1015

1016

1017

1018

1019

1020
Sabo, R.D., Nelson, D.M., Eshleman, K.N., 2016. Episodic, seasonal, and annual export of atmospheric and microbial nitrate from a temperate forest: MICROBIAL AND ATMOSPHERIC NITRATE EXPORT. Geophys. Res. Lett. 43, 683-691. https://doi.org/10.1002/2015GL066758

Savarino, J., Kaiser, J., Morin, S., Sigman, D.M., Thiemens, M.H., 2007. Nitrogen and oxygen isotopic constraints on the origin of atmospheric nitrate in coastal Antarctica.

Atmospheric Chem. Phys. 7, 1925-1945. https://doi.org/10.5194/acp-7-1925-2007

Sebestyen, S.D., Shanley, J.B., Boyer, E.W., Kendall, C., Doctor, D.H., 2014. Coupled hydrological and biogeochemical processes controlling variability of nitrogen species in streamflow during autumn in an upland forest: STREAM N DYNAMICS DURING AUTUMN. Water Resour. Res. 50, 1569-1591. https://doi.org/10.1002/2013WR013670 Shi, G., Buffen, A.M., Hastings, M.G., Li, C., Ma, H., Li, Y., Sun, B., An, C., Jiang, S., 2015. Investigation of post-depositional processing of nitrate in East Antarctic snow: isotopic constraints on photolytic loss, re-oxidation, and source inputs. Atmospheric Chem. Phys. 15, 9435-9453. https://doi.org/10.5194/acp-15-9435-2015

Snider, D.M., Spoelstra, J., Schiff, S.L., Venkiteswaran, J.J., 2010. Stable Oxygen Isotope Ratios of Nitrate Produced from Nitrification: 180-Labeled Water Incubations of Agricultural and Temperate Forest Soils. Environ. Sci. Technol. 44, 5358-5364. https://doi.org/10.1021/es1002567

Sorensen, P.O., Templer, P.H., Christenson, L., Duran, J., Fahey, T., Fisk, M.C., Groffman, P.M., Morse, J.L., Finzi, A.C., 2016. Reduced snow cover alters root-microbe interactions and decreases nitrification rates in a northern hardwood forest. Ecology 97, 3359-3368. https://doi.org/10.1002/ecy.1599

Spoelstra, J., Schiff, S.L., Hazlett, P.W., Jeffries, D.S., Semkin, R.G., 2007. The isotopic composition of nitrate produced from nitrification in a hardwood forest floor. Geochim. Cosmochim. Acta 71, 3757-3771. https://doi.org/10.1016/j.gca.2007.05.021

Stoewer, M.M., Knöller, K., Stumpp, C., 2015. Tracing freshwater nitrate sources in prealpine groundwater catchments using environmental tracers. J. Hydrol. 524, 753-767. https://doi.org/10.1016/j.jhydrol.2015.03.022

Templer, P.H., Weathers, K.C., 2011. Use of mixed ion exchange resin and the denitrifier method to determine isotopic values of nitrate in atmospheric deposition and canopy throughfall. Atmos. Environ. 45, 2017-2020.

https://doi.org/10.1016/j.atmosenv.2011.01.035

Templer, P.H., Weathers, K.C., Lindsey, A., Lenoir, K., Scott, L., 2015. Atmospheric inputs and nitrogen saturation status in and adjacent to Class I wilderness areas of the northeastern US. Oecologia 177, 5-15. https://doi.org/10.1007/s00442-014-3121-5 Thiemens, M.H., 2006. History and applications of mass-independent isotope effects. Annu Rev Earth Planet Sci 34, 217-262.

Tomaz, S., Jaffrezo, J.-L., Favez, O., Perraudin, E., Villenave, E., Albinet, A., 2017. Sources and atmospheric chemistry of oxy-and nitro-PAHs in the ambient air of Grenoble 
(France). Atmos. Environ. 161, 144-154.

1022

1023

1024

1025

1026

1027

1028

1029

1030

1031

1032

1033

1034

1035

1036

1037

1038

1039

1040

1041

1042

1043

1044

1045

1046

1047

1048

1049

1050

1051

1052

1053

1054

1055

1056

1057

1058

1059

1060

1061

1062

1063

1064

1065

1066

1067

1068

1069

https://doi.org/10.1016/j.atmosenv.2017.04.042

Treibergs, L.A., Granger, J., 2017. Enzyme level $\mathrm{N}$ and $\mathrm{O}$ isotope effects of assimilatory and dissimilatory nitrate reduction: Enzyme level $\mathrm{N}$ and $\mathrm{O}$ isotope effects. Limnol. Oceanogr. 62, 272-288. https://doi.org/10.1002/lno.10393

Tsunogai, U., Komatsu, D.D., Daita, S., Kazemi, G.A., Nakagawa, F., Noguchi, I., Zhang, J., 2010. Tracing the fate of atmospheric nitrate deposited onto a forest ecosystem in Eastern Asia using $\Delta 17$ 0. Atmospheric Chem. Phys. 10, 1809-1820.

Tsunogai, U., Komatsu, D.D., Ohyama, T., Suzuki, A., Nakagawa, F., Noguchi, I., Takagi, K., Nomura, M., Fukuzawa, K., Shibata, H., 2014. Quantifying the effects of clear-cutting and strip-cutting on nitrate dynamics in a forested watershed using triple oxygen isotopes as tracers. Biogeosciences 11, 5411-5424. https://doi.org/10.5194/bg-11-5411-2014 Tsunogai, U., Miyauchi, T., Ohyama, T., Komatsu, D.D., Nakagawa, F., Obata, Y., Sato, K., Ohizumi, T., 2016. Accurate and precise quantification of atmospheric nitrate in streams draining land of various uses by using triple oxygen isotopes as tracers. Biogeosciences 13, 3441-3459. https://doi.org/10.5194/bg-13-3441-2016

Vankoughnett, M.R., Henry, H.A.L., 2013. Combined Effects of Soil Freezing and N Addition on Losses and Interception of N Over Winter and Summer. Ecosystems 16, 694-703. https://doi.org/10.1007/s10021-013-9642-7

Vitousek, P.M., Aber, J.D., Howarth, R.W., Likens, G.E., Matson, P.A., Schindler, D.W., Schlesinger, W.H., Tilman, D.G., 1997. HUMAN ALTERATION OF THE GLOBAL NITROGEN CYCLE: SOURCES AND CONSEQUENCES. Ecol. Appl. 7, 737-750.

https://doi.org/10.1890/1051-0761(1997)007[0737:HAOTGN]2.0.C0;2

Wankel, S.D., Kendall, C., Francis, C.A., Paytan, A., 2006. Nitrogen sources and cycling in the San Francisco Bay Estuary: A nitrate dual isotopic composition approach. Limnol. Oceanogr. 51, 1654-1664.

Wasiuta, V., Lafrenière, M.J., Norman, A.-L., Hastings, M.G., 2015. Summer deposition of sulfate and reactive nitrogen to two alpine valleys in the Canadian Rocky Mountains. Atmos. Environ. 101, 270-285. https://doi.org/10.1016/j.atmosenv.2014.10.041 Weijs, S.V., Mutzner, R., Parlange, M.B., 2013. Could electrical conductivity replace water level in rating curves for alpine streams?: ELECTRICAL CONDUCTIVITY STREAMFLOW RATING CURVES. Water Resour. Res. 49, 343-351.

https://doi.org/10.1029/2012WR012181

Wexler, S.K., Goodale, C.L., McGuire, K.J., Bailey, S.W., Groffman, P.M., 2014. Isotopic signals of summer denitrification in a northern hardwood forested catchment. Proc. Natl. Acad. Sci. 111, 16413-16418. https://doi.org/10.1073/pnas.1404321111 Williams, J.J., Nurse, A., Saros, J.E., Riedel, J., Beutel, M., 2016. Effects of glaciers on nutrient concentrations and phytoplankton in lakes within the Northern Cascades Mountains (USA). Biogeochemistry 131, 373-385. https://doi.org/10.1007/s10533016-0264-y

Williams, M.W., Knauf, M., Cory, R., Caine, N., Liu, F., 2007. Nitrate content and potential microbial signature of rock glacier outflow, Colorado Front Range. Earth Surf. Process. Landf. 32, 1032-1047. https://doi.org/10.1002/esp.1455

Williams, M.W., Melack, J.M., 1991. Solute chemistry of snowmelt and runoff in an Alpine Basin, Sierra Nevada. Water Resour. Res. 27, 1575-1588.

https://doi.org/10.1029/90WR02774

Williams, M.W., Seibold, C., Chowanski, K., 2009. Storage and release of solutes from a subalpine seasonal snowpack: soil and stream water response, Niwot Ridge, Colorado. Biogeochemistry 95, 77-94. https://doi.org/10.1007/s10533-009-9288-x 
1070 Yang, Y.-Y., Toor, G.S., 2016. $\delta{ }^{15} \mathrm{~N}$ and $\delta^{18} \mathrm{O}$ Reveal the Sources of Nitrate-Nitrogen in 1071 Urban Residential Stormwater Runoff. Environ. Sci. Technol.

1072 https://doi.org/10.1021/acs.est.5b05353

1073 Ye, C., Gao, H., Zhang, N., Zhou, X., 2016. Photolysis of Nitric Acid and Nitrate on Natural 1074 and Artificial Surfaces. Environ. Sci. Technol. 50, 3530-3536.

1075 https://doi.org/10.1021/acs.est.5b05032 


\begin{tabular}{|c|c|c|c|c|c|c|}
\hline Watershed & $\begin{array}{l}\text { S-upper } \\
\text { montane }\end{array}$ & $\begin{array}{l}\mathrm{N} \text {-upper } \\
\text { montane }\end{array}$ & $\begin{array}{c}\text { Mid } \\
\text { montane }\end{array}$ & $\begin{array}{l}\text { Lower } \\
\text { montane }\end{array}$ & Upper urban & Lower Urban \\
\hline Main regime & Snowmelt & Glacier melt & Snowmelt & Snowmelt & $\begin{array}{l}\text { Snowmelt - } \\
\text { Rainfall }\end{array}$ & $\begin{array}{l}\text { Snowmelt - } \\
\text { Rainfall }\end{array}$ \\
\hline $\begin{array}{c}\text { Altitude range (m } \\
\text { a.s.I.) }\end{array}$ & 1667-2725 & $1667-3155$ & 1618-1980 & $1050-4088$ & $210-2650$ & $210-4088$ \\
\hline Size $\left(\mathrm{km}^{2}\right)$ & 3.4 & 5.3 & 0.5 & 220 & 5720 & 3600 \\
\hline Mean slope (\%) & 25 & 30 & 17 & 28 & 22 & 22 \\
\hline Geology & Calcareous & $\begin{array}{c}\text { Granitic and } \\
\text { ancient } \\
\text { volcanic } \\
\text { rocks }\end{array}$ & Calcareous & $\begin{array}{c}60 \% \text { Marls } \\
\text { and } \\
\text { carbonates, } \\
40 \% \\
\text { Metamorphic } \\
\text { and } \\
\text { crystalline } \\
\text { rocks }\end{array}$ & $\begin{array}{c}77 \% \text { Marls } \\
\text { and } \\
\text { carbonates, } \\
15 \% \\
\text { Metamorphic } \\
\text { and crystalline } \\
\text { rocks, } 8 \% \\
\text { glacial } \\
\text { deposits }\end{array}$ & $\begin{array}{l}\text { Crystalline } \\
\text { rocks } \\
\text { (granite, } \\
\text { gneiss and } \\
\text { amphibolite) }\end{array}$ \\
\hline Land cover & $\begin{array}{c}30 \% \text { alpine } \\
\text { meadows } \\
\text { (grazed), } \\
27 \% \\
\text { uncovered, } \\
26 \% \\
\text { abandoned } \\
\text { grasslands, } \\
13 \% \\
\text { terraced } \\
\text { meadows } \\
\text { (mown for } \\
\text { hay), some } \\
\text { habitations }\end{array}$ & $\begin{array}{c}\text { Mostly } \\
\text { uncovered } \\
\text { and } \\
\text { abandoned } \\
\text { grasslands }\end{array}$ & $\begin{array}{c}80 \% \\
\text { terraced } \\
\text { meadows } \\
\text { (mown for } \\
\text { hay), 13\% } \\
\text { alpine } \\
\text { meadows, } \\
\text { one village }\end{array}$ & $\begin{array}{c}60 \% \\
\text { Uncovered, } \\
40 \% \text { Forest or } \\
\text { low } \\
\text { vegetation, a } \\
\text { few villages }\end{array}$ & $\begin{array}{l}74 \% \text { Forest } \\
\text { and semi- } \\
\text { natural } \\
\text { vegetation, } \\
22 \% \\
\text { Agricultural } \\
\text { fields, } 4 \% \\
\text { Urbanized } \\
\text { areas }\end{array}$ & $\begin{array}{c}81 \% \text { Forest } \\
\text { and semi- } \\
\text { natural } \\
\text { vegetation, } \\
16 \% \\
\text { Agricultural } \\
\text { fields, } 3 \% \\
\text { urbanized } \\
\text { areas }\end{array}$ \\
\hline
\end{tabular}


Table 1 Characteristics of the Romanche Valley and Isere watersheds along the montane to urban gradient 

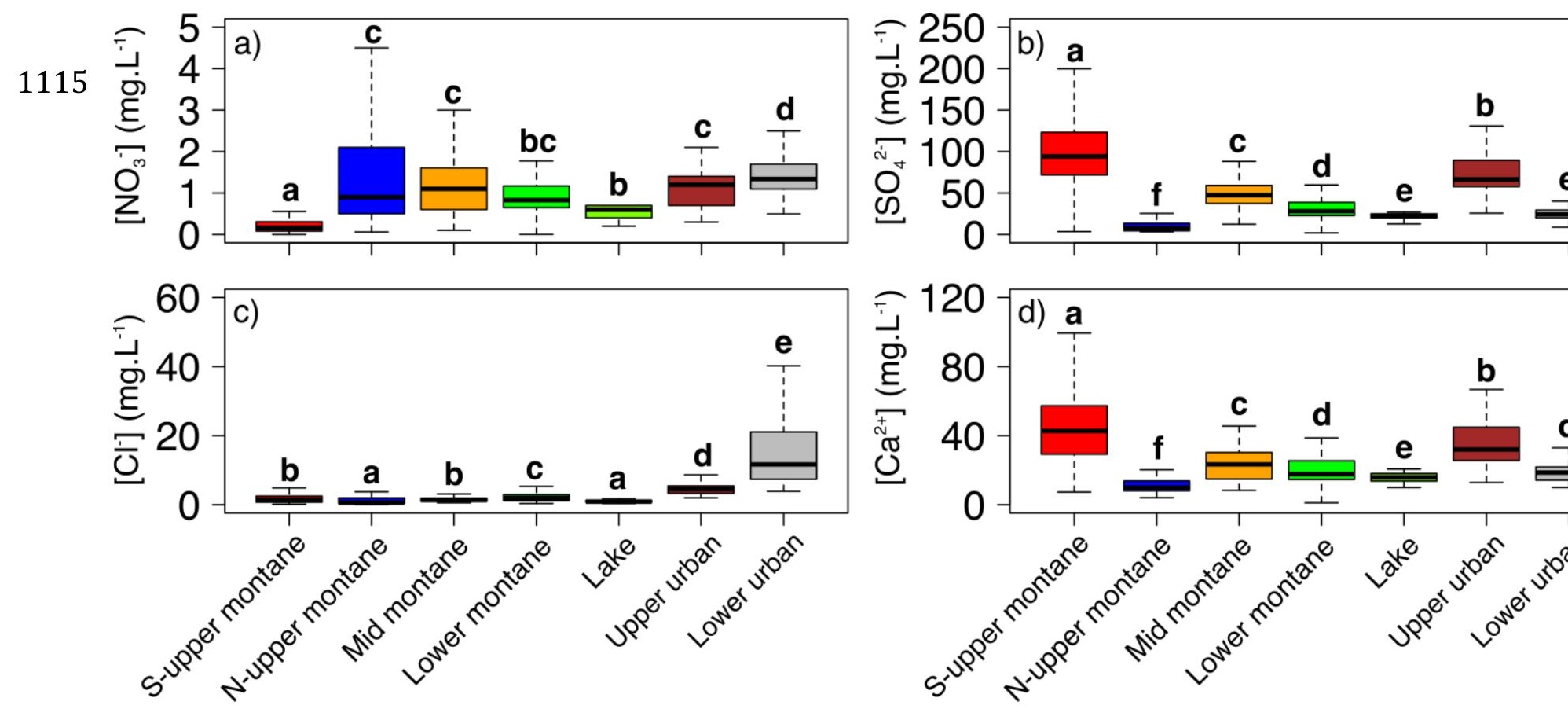

Figure 1 Two years solute concentrations in streams, with a) $\left.\left[\mathrm{NO}_{3}^{-}\right]\left(\mathrm{mg} \mathrm{L}^{-1}\right), \mathrm{b}\right)$ $\left.\left[\mathrm{SO}_{4}{ }^{2-}\right]\left(\mathrm{mg} \mathrm{L}^{-1}\right), \mathrm{c}\right)\left[\mathrm{Cl}^{-}\right]\left(\mathrm{mg} \mathrm{L}^{-1}\right)$ and d) $\left[\mathrm{Ca}^{2+}\right]\left(\mathrm{mg} \mathrm{L}^{-1}\right)$. Different letters denote significant differences in $\mathrm{NO}_{3}{ }^{-}$isotopic composition across sites. (e.g., a site with ab letters is significantly different from sites with letters from $c$ onwards, but not significantly different from sites with $a$ or $b$ letters). 

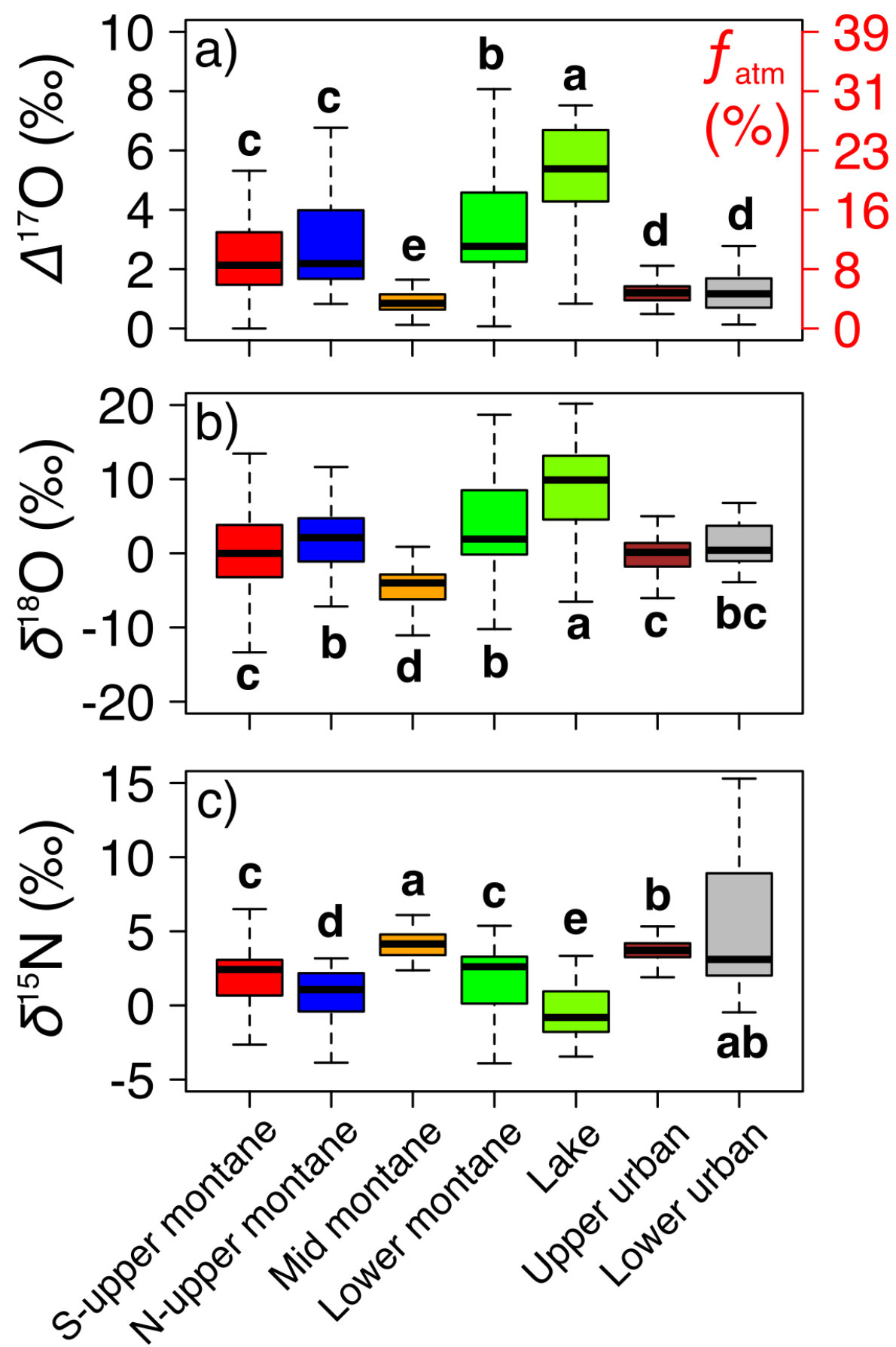

1117 Figure 2 Two years isotopic composition of $\mathrm{NO}_{3}{ }^{-}$in streams, with a) $\Delta^{17} \mathrm{O}(\%$ ) (and 1118 corresponding $f_{\text {atm }}(\%)$ on the red y-axis), b) $\delta^{18} \mathrm{O}(\%)$ and c) $\delta^{15} \mathrm{~N}(\%)$. Different 1119 letters denote significant differences in $\mathrm{NO}_{3}{ }^{-}$isotopic composition among sites (e.g., a 1120 site with ab letters is significantly different from sites with letters from $c$ onwards, but 1121 not significantly different from sites with $a$ or $b$ letters). 

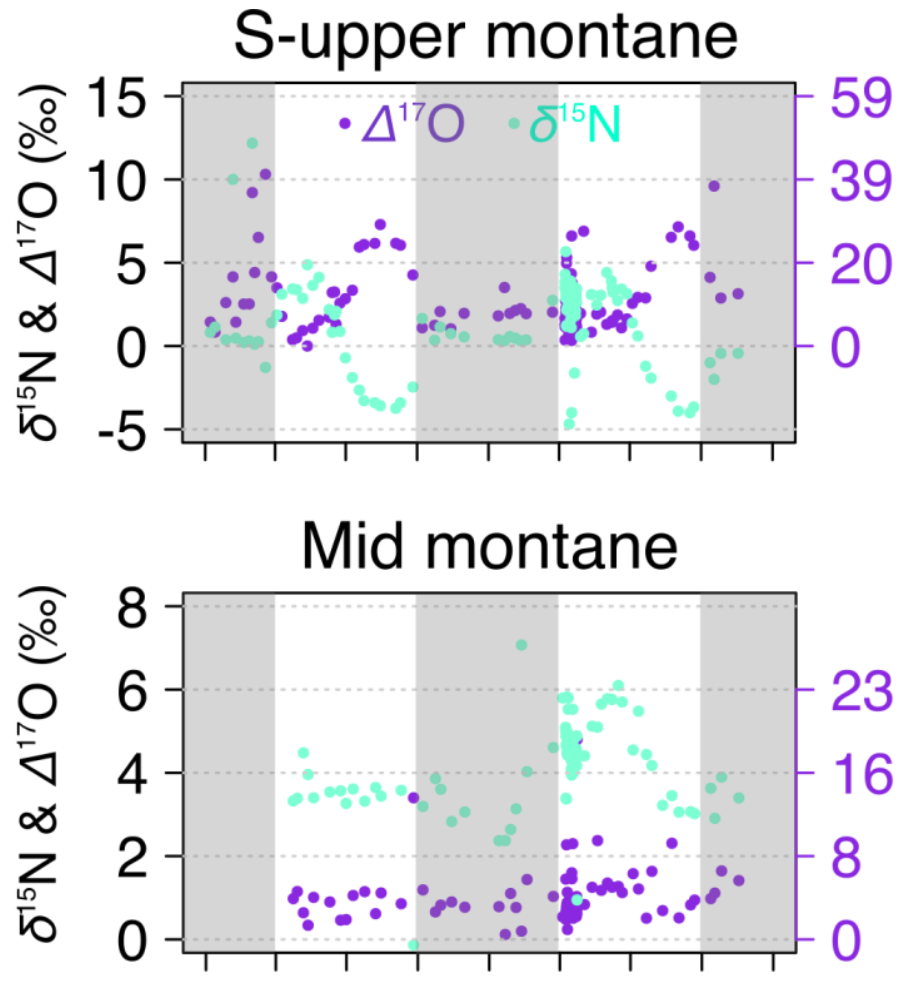

Upper urban

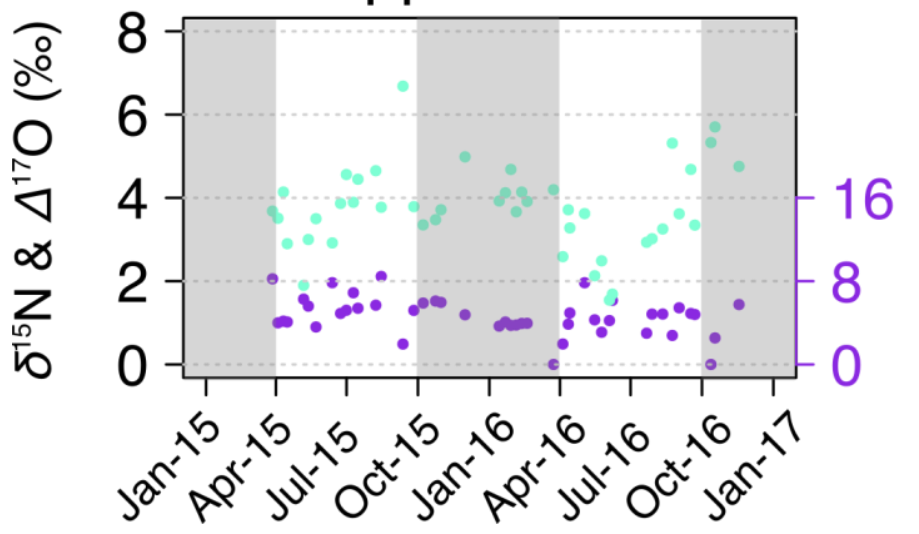

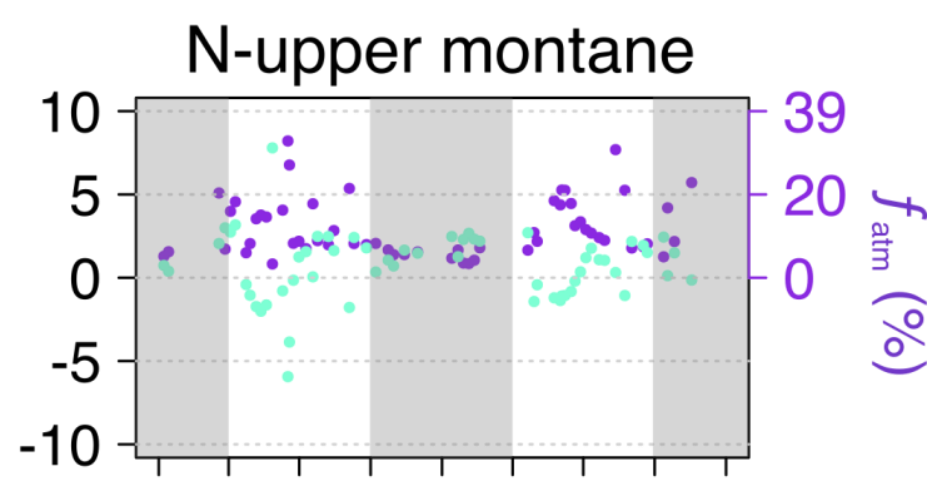

Lower montane \& Lake

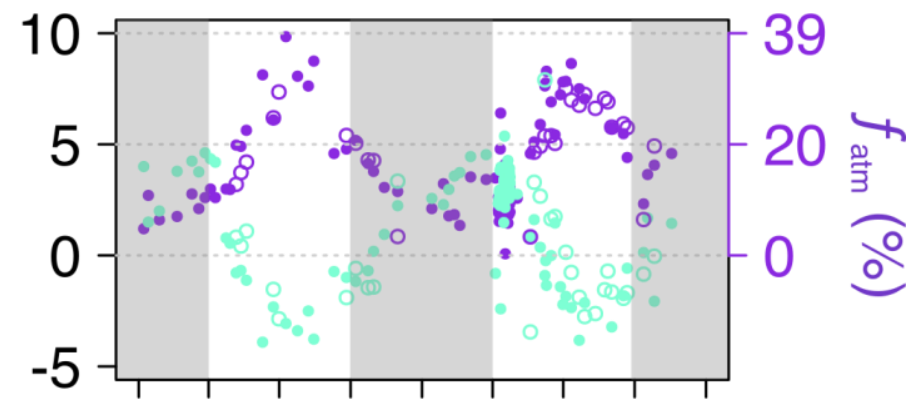

Lower urban

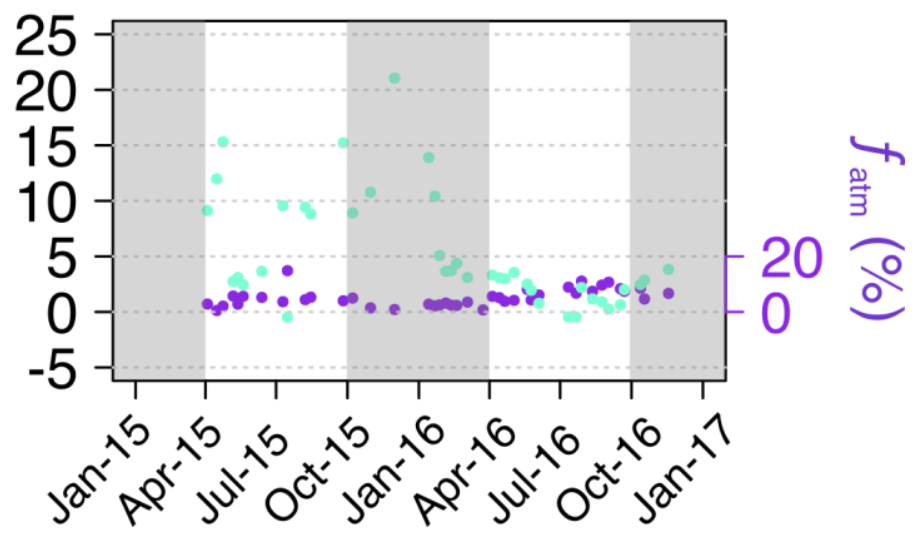

1122 Figure 3 Seasonal variations of $\Delta^{17} \mathrm{O}-\mathrm{NO}_{3}{ }^{-}$and $\delta^{15} \mathrm{~N}-\mathrm{NO}_{3}{ }^{-}(\%)$ in streams. Point 1123 colors denote isotopes as indicated in legend. Range of corresponding $f_{\text {atm }}(\%)$ is 1124 indicated on the secondary $y$-axis. on the red y-axis). Highlighted in grey is the 1125 dormant season (October-April). Note the different y-axes scales across the different 1126 panels. 


\begin{tabular}{|c|c|c|c|c|c|c|c|c|}
\hline & \multicolumn{2}{|c|}{$\begin{array}{c}\text { Mean discharge- } \\
\text { weighted annual } \\
{\left[\mathrm{NO}_{3}^{-}\right]\left(\mathrm{mgL}^{-1}\right)}\end{array}$} & \multicolumn{2}{|c|}{$\begin{array}{c}\text { Mean discharge } \\
\text { weighted } f_{\text {atm }}(\%) \\
\text { based on } \Delta^{17} \mathrm{O} \\
(\% \circ)\end{array}$} & \multicolumn{2}{|c|}{$\begin{array}{l}\text { Total } \mathrm{NO}_{3}^{-} \text {flux } \\
\left(\mathrm{kg} \mathrm{N} \mathrm{ha}^{-1} \mathrm{yr}^{-1}\right)\end{array}$} & \multicolumn{2}{|c|}{$\begin{array}{l}\text { Total } \mathrm{NO}_{3}^{-} \text {atm flux } \\
\left(\mathrm{kg} \mathrm{N} \mathrm{ha}^{-1} \mathrm{yr}^{-1}\right)\end{array}$} \\
\hline & 2015 & 2016 & 2015 & 2016 & 2015 & 2016 & 2015 & 2016 \\
\hline $\begin{array}{l}\text { Lower } \\
\text { montane }\end{array}$ & 1.0 & 0.9 & 22 & 19 & 1.9 & 1.4 & 0.4 & 0.3 \\
\hline $\begin{array}{l}\text { Upper } \\
\text { urban }\end{array}$ & 1.0 & 1.2 & 5 & 4 & 2.0 & 2.6 & 0.1 & 0.1 \\
\hline $\begin{array}{l}\text { Lower } \\
\text { urban }\end{array}$ & 1.7 & 1.3 & 4 & 5 & 4.8 & 2.1 & 0.2 & 0.1 \\
\hline
\end{tabular}

1127 Table 2 Mean discharge-weighted annual $\left[\mathrm{NO}_{3}^{-}\right]$and associated $\left(\mathrm{mgL}^{-1}\right)$ and $f_{\text {atm }}$ 1128 (\%), annual fluxes of total $\mathrm{NO}_{3}{ }^{-}$and total $\mathrm{NO}_{3}{ }^{-}$atm in streams and deduced annual 1129 contribution of $\mathrm{NO}_{3}{ }^{-}$atm yield to the total $\mathrm{NO}_{3}$ flux at three sites along the montane to 1130 urban gradient for years 2015 and 2016. 

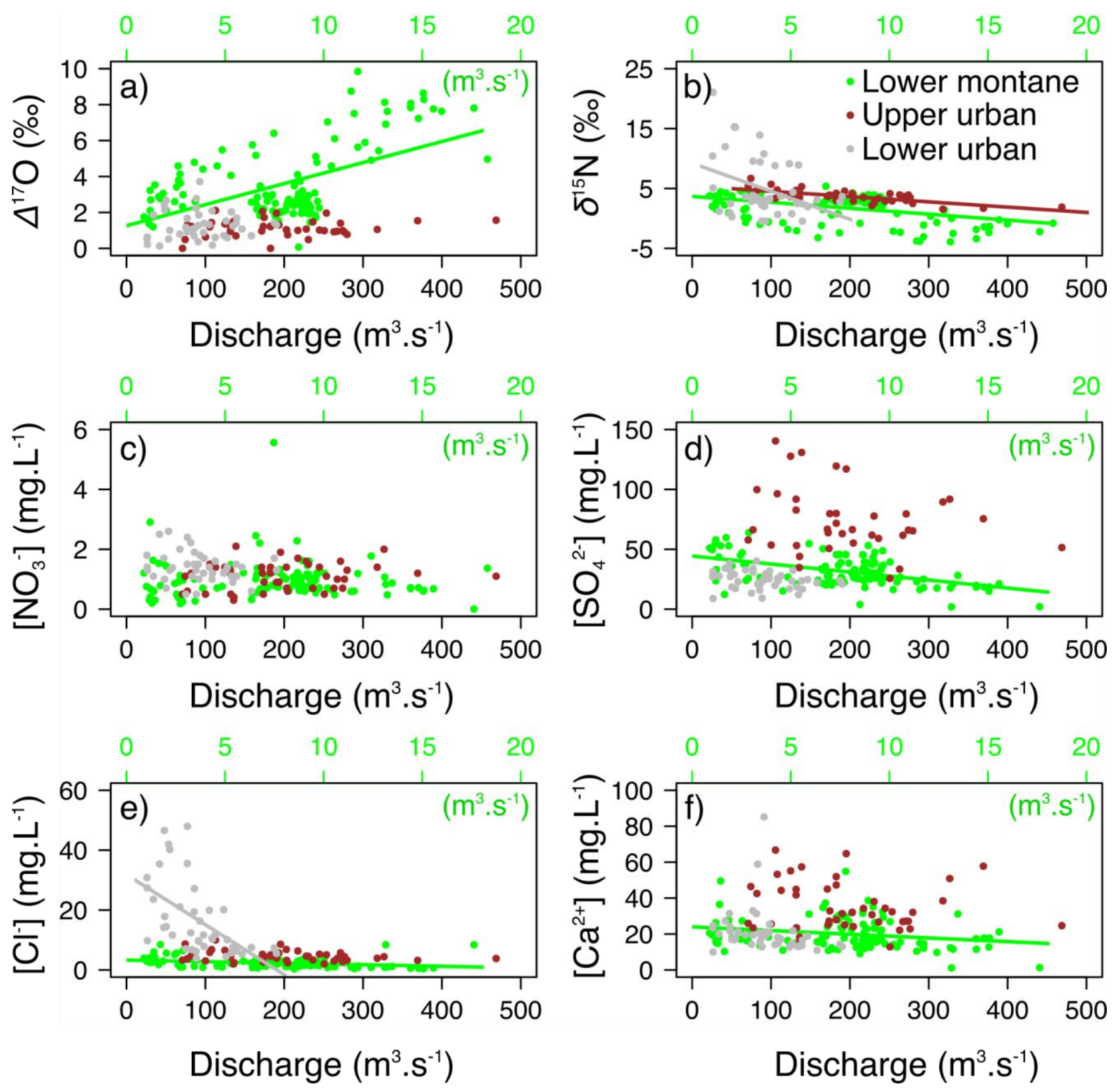

1131 Figure 4 Relationships of nitrate isotopes and solutes concentration with discharge 1132 at three sites along the montane to urban gradient. Linear correlations were plotted only if significant. Note the differences in the $y$-axis scales among the panels, and the specific $\mathrm{x}$-axis for discharge at the lower montane site (in green). Point colors denote sites as indicated in legend. 

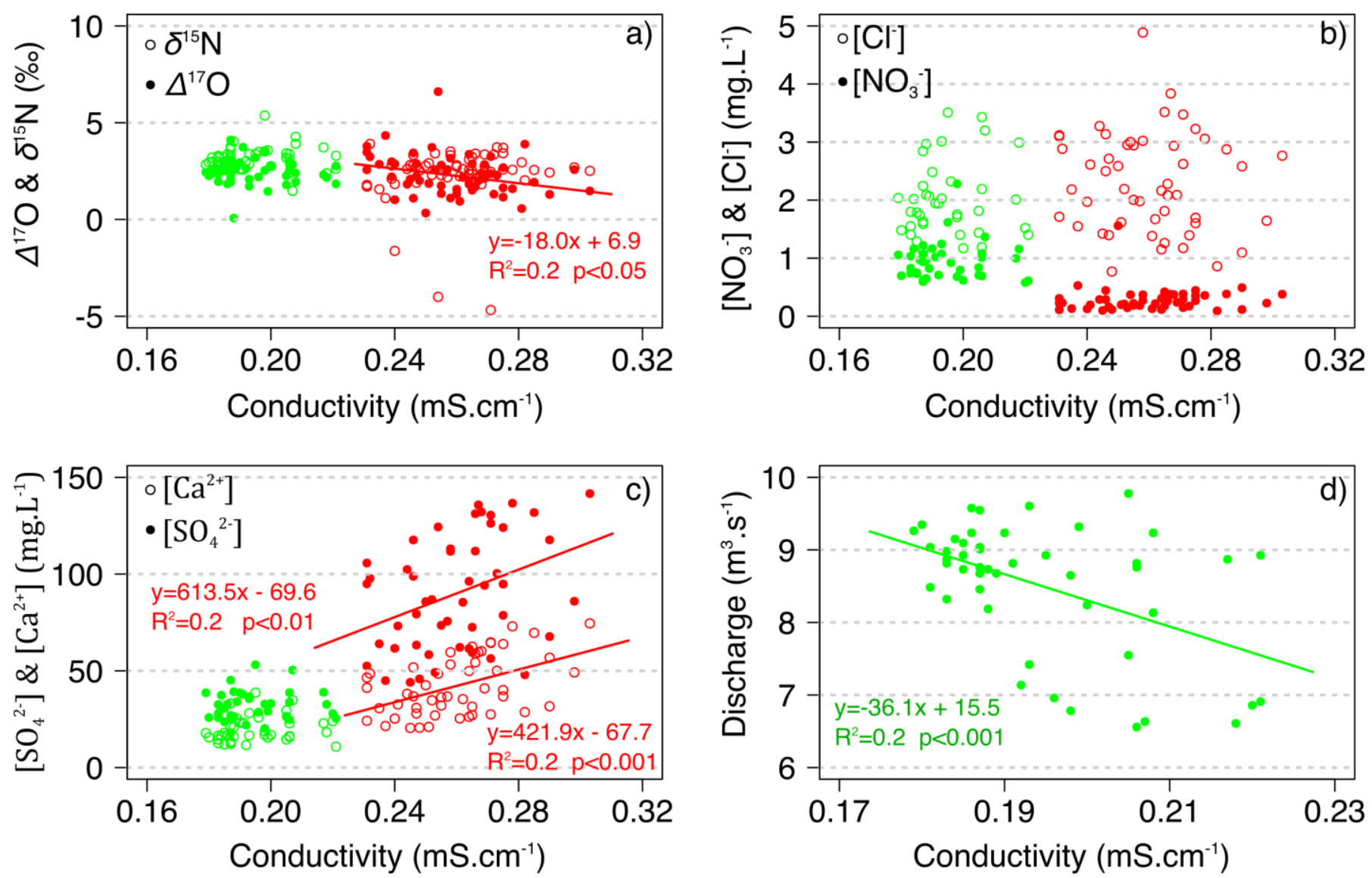

1136 Figure 5 Relationships of $\mathrm{NO}_{3}{ }^{-}$isotopes, solute concentration and discharge with conductivity during snowmelt (April 8 to April 24 in 2016) at the S-upper montane (in red) and the lower montane (in green) sites. Linear regressions were plotted only if significant. Full or open circles feature either a) different $\mathrm{NO}_{3}{ }^{-}$isotopes or b) and c) different solute concentrations. 


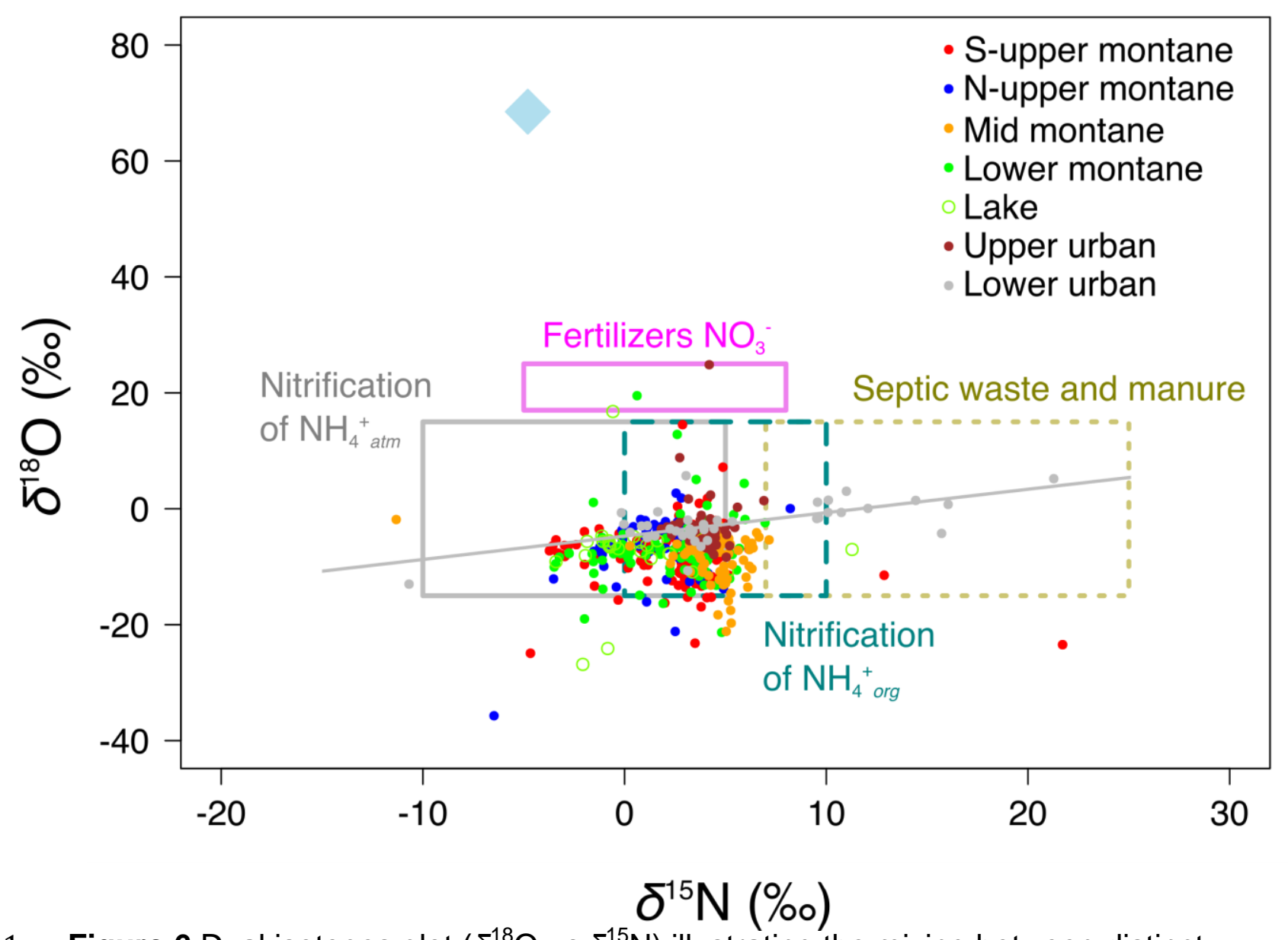

1141 Figure 6 Dual isotopes plot $\left(\delta^{18} \mathrm{O} v s \delta^{15} \mathrm{~N}\right)$ illustrating the mixing between distinct 1142 sources of $\mathrm{NO}_{3}{ }^{-}$ter (non-atmospheric) in streams. All isotopic values were obtained by 1143 the $\Delta^{17} \mathrm{O}$ transform of $\mathrm{NO}_{3}{ }^{-}$collected at all sites (see Methods). The colored boxes 1144 represent the reported range for $\mathrm{NO}_{3}{ }^{-}$terrestrial sources, featuring atmospheric ammonium $\left(\mathrm{NH}_{4}{ }^{+}\right.$atm $)$in grey, mineralized ammonium $\left(\mathrm{NH}_{4}{ }^{+}\right.$org $)$in turquoise, manure or sewage derived $\mathrm{NH}_{4}{ }^{+}$in beige and fertilizers $\mathrm{NO}_{3}{ }^{-}$in violet (Kendall et al., 2007). Linear regressions were plotted only when significant. The blue diamond reflects the isotopic composition of $\mathrm{NO}_{3}{ }^{-}$atm as measured in this study. Point colors denote sites as indicated in legend. 


\begin{tabular}{|c|c|c|c|}
\hline & $\begin{array}{c}\text { Mean annual } \\
\delta^{18} \mathrm{O}-\mathrm{NO}_{3}^{-}(\% \circ)\end{array}$ & $\begin{array}{c}\text { Mean annual } \\
\delta^{18} \mathrm{O}^{-\mathrm{NO}_{3}^{-}} \text {ter }(\%) \text { and } \\
\text { deduced } \% \mathrm{NO}_{3}^{-} \text {atm } \\
\end{array}$ & $\begin{array}{c}\text { Calculated } \delta^{-18} \mathrm{O}_{-} \mathrm{NO}_{3}^{-} \text {nit } \\
\text { (\%o) and deduced \% } \\
\mathrm{NO}_{3}^{-} \text {atm } \\
\end{array}$ \\
\hline S-upper montane & $0.7 \pm 6.6$ & $-7.7 \pm 4.811 \pm 7^{a}$ & $-3.3 \pm 3.45 \pm 9^{b}$ \\
\hline N-uppermontane & $2.8 \pm 4.2$ & $-6.3 \pm 5.612 \pm 7^{a}$ & $-3.3 \pm 3.48 \pm 6^{b}$ \\
\hline Mid-montane & $-4.9 \pm 4.1$ & $-8.0 \pm 3.74 \pm 3^{a}$ & $-3.3 \pm 3.40 \pm 5^{b}$ \\
\hline Lower montane & $4.1 \pm 6.6$ & $-6.8 \pm 6.714 \pm 8^{a}$ & $-3.3 \pm 3.410 \pm 9^{b}$ \\
\hline Lake & $8.6 \pm 6.2$ & $-7.3 \pm 4.820 \pm 7^{a}$ & $-3.3 \pm 3.416 \pm 8^{a}$ \\
\hline Upper urban & $0.9 \pm 5.7$ & $-2.8 \pm 5.35 \pm 2^{a}$ & $2.3 \pm 4.20 \pm 4^{b}$ \\
\hline Lower urban & $1.1 \pm 3.8$ & $-2.6 \pm 3.55 \pm 3^{a}$ & $2.3 \pm 4.20 \pm 6^{b}$ \\
\hline
\end{tabular}

1150 Table 3 The second column gives the mean annual $\delta^{18} \mathrm{O}_{-1} \mathrm{NO}_{3}{ }^{-}(\%)$ measured in 1151 streams. The third column shows the mean annual $\delta^{18} \mathrm{O}-\mathrm{NO}_{3}{ }^{-}$ter $(\%)$ after samples 1152 isotopic composition was corrected for the atmospheric imprint (see Methods), and 1153 the corresponding proportion of $\mathrm{NO}_{3}{ }^{-}$atm when using the corrected value as microbial 1154 end-member. Fourth column presents the calculated theoretical $\delta^{18} \mathrm{O}_{-1} \mathrm{NO}_{3}{ }^{-}{ }_{\text {nit }}$ when 1155 using the approach detailed in section 4.3, and the corresponding proportion of $\mathrm{NO}_{3}{ }^{-}$ 1156 atm when using this theoretical value as microbial end-member. Superscript letters 1157 indicate significant differences in the proportion of $\mathrm{NO}_{3}{ }^{-}$atm inferred by both methods $1158(p<0.05)$. 